\title{
Learning styles of extension agents responsible for pesticide re- certification training programs in West Virginia
}

Anne M. Custer-Walker

West Virginia University

Follow this and additional works at: https://researchrepository.wvu.edu/etd

\section{Recommended Citation}

Custer-Walker, Anne M., "Learning styles of extension agents responsible for pesticide re-certification training programs in West Virginia" (2004). Graduate Theses, Dissertations, and Problem Reports. 1960. https://researchrepository.wvu.edu/etd/1960

This Thesis is protected by copyright and/or related rights. It has been brought to you by the The Research Repository @ WVU with permission from the rights-holder(s). You are free to use this Thesis in any way that is permitted by the copyright and related rights legislation that applies to your use. For other uses you must obtain permission from the rights-holder(s) directly, unless additional rights are indicated by a Creative Commons license in the record and/ or on the work itself. This Thesis has been accepted for inclusion in WVU Graduate Theses, Dissertations, and Problem Reports collection by an authorized administrator of The Research Repository @ WVU. For more information, please contact researchrepository@mail.wvu.edu. 
Learning Styles of Extension Agents Responsible for Pesticide Re-Certification Training Programs in West Virginia

Anne M. Custer-Walker

Thesis submitted to the Davis College of Agriculture, Forestry, and Consumer Sciences at West Virginia University in partial fulfillment of the requirements for the degree of

Master of Science

in

Agricultural Education

Stacy A. Gartin, Ph.D., Chair

Harry N. Boone, Jr., Ph.D.

Jean M. Woloshuk, Ed.D.

Division of Resource Management

Morgantown, West Virginia

2004

Keywords: Extension Agents, Pesticide Re-Certification, Learning Styles, Experiential Learning Theory 


\section{ABSTRACT \\ Learning Styles of Extension Agents Responsible for Pesticide Re-Certification Training Programs in West Virginia}

Anne M. Custer-Walker

As a condition of license renewal necessary for restricted-use pesticides, private pesticide applicators are required to accumulate five hours or 10 continuing education units (CEUs) every three years. These programs provide valuable experiential learning opportunities to adult learners. As a result, adult learning is a topic of research. Kolb's Learning Style Inventory (LSI) has been used in research for many years to determine learning style preferences of adults. The purpose of the study was to categorize each agent according to their learning style and to determine if relationships exist between learning style preferences and the agents' major program area, Extension experience, gender, age, and area of study of their Bachelors and Master's degree. Forty-eight Extension agents were mailed Kolb's LSI and a demographic survey. Thirty-two agents responded. Converger was the dominant learning style preference. No significant associations were found to exist between the demographic factors and the agents' learning style preferences. 


\section{DEDICATION}

Dedicated to the loving memory of:

Walter F. and Barbara A. Perry 


\section{ACKNOWLEDGEMENTS}

I would like to first acknowledge the professors who served on my graduate committee by offering appreciation to Dr. Stacy Gartin, Dr. Harry Boone, and Dr. Jean Woloshuk. All three have been helpful and patient through the whole process of earning my Master's Degree in Agricultural Education.

Secondly, I would like to extend my sincere appreciation to several people who have influenced me in my endeavors and have offered their unselfish support. My father Eddie Custer and stepmother Melodie; Linda Custer; and Jack and Phyllis Williams have offered continuous support from the time I was a child. Their selfless attitudes have taught me to be appreciative for the goals I have achieved.

I would like to thank my close friends, Christina Reed, Beth Cappone, and Drema Paugh for being wonderful individuals who have helped me personally and professionally.

I also want to extend my most sincere and loving appreciation to my husband, Samuel Walker. He has taught me determination, patience, and perseverance. I am looking forward to a lifetime of memories. 


\section{TABLE OF CONTENTS}

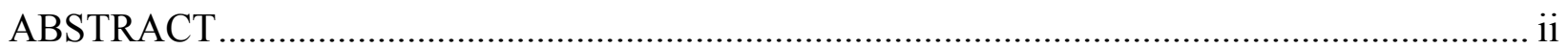

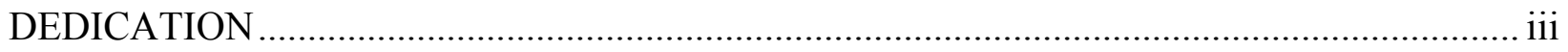

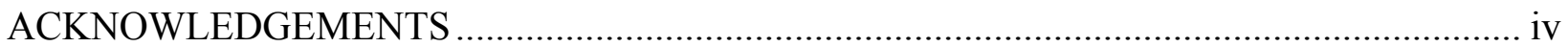

LIST OF TABLES ................................................................................................ vii

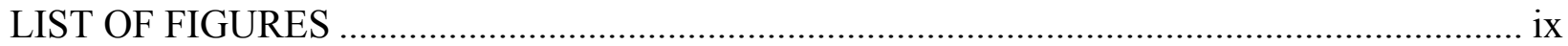

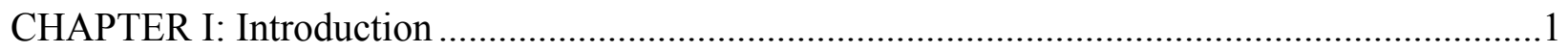

Background and Setting ..............................................................................

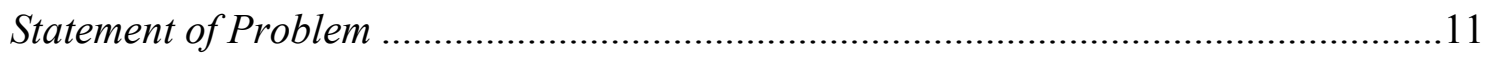

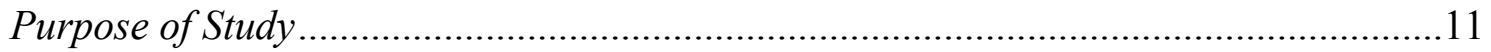

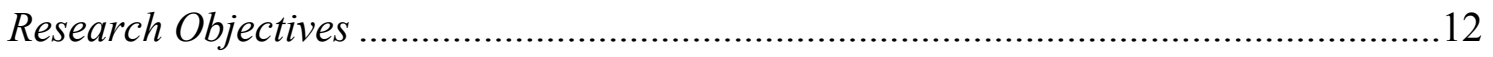

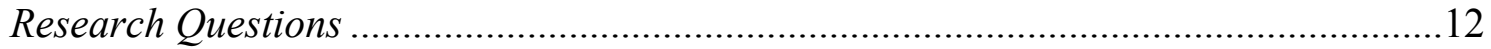

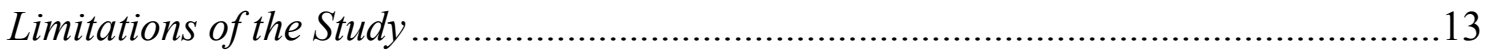

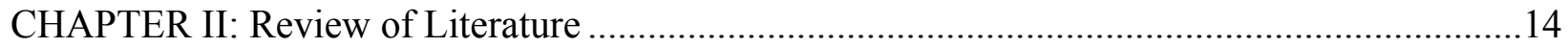

Kolb 's Theory of Experiential Learning ............................................................... 15

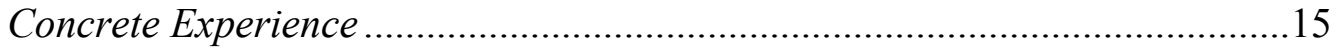

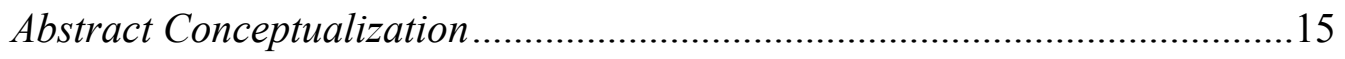

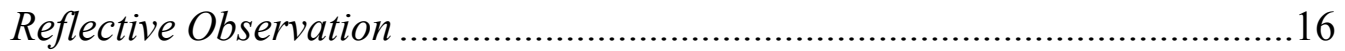

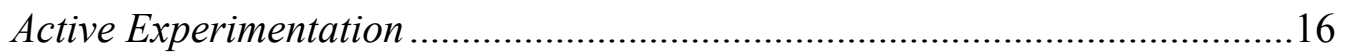

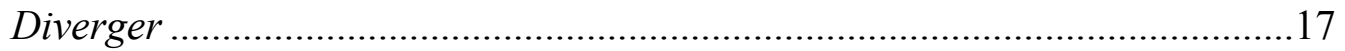

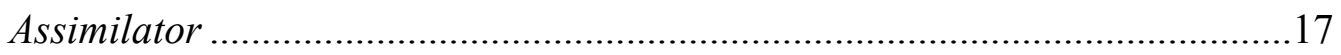

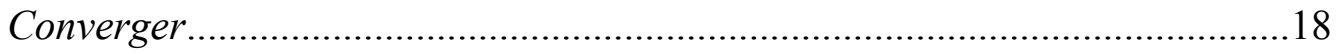

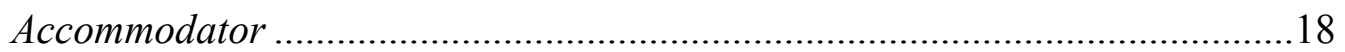


Studies Using Kolb's Learning Style Inventory …………………............................18

Studies of Adult Learner Comprehension ……………………………………….......20

Studies Concerning Methods of Program Delivery ......................................................23

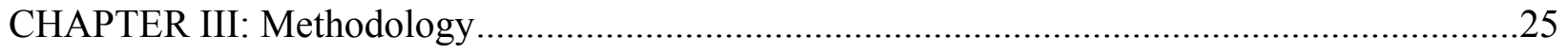

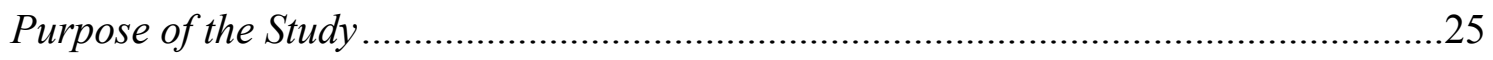

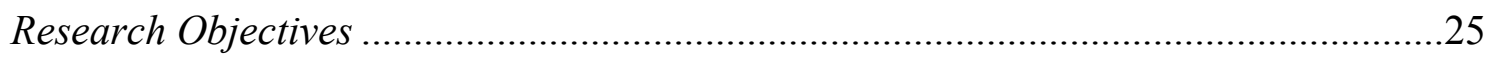

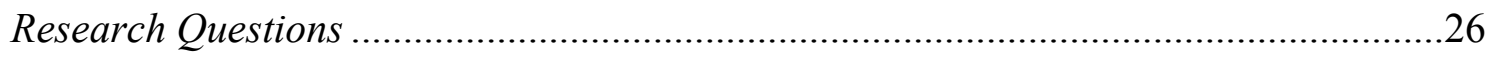

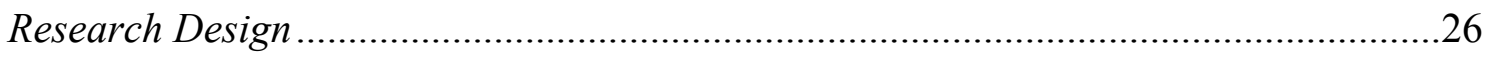

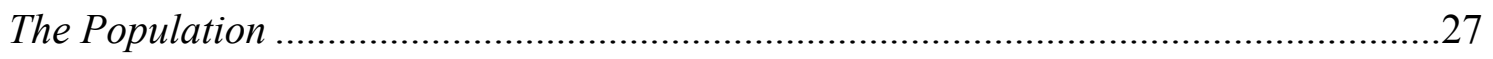

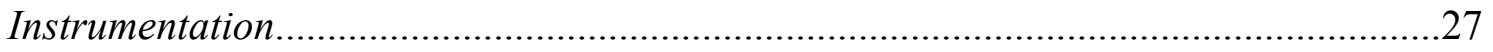

Reliability of Kolb 's 1985 Learning Style Inventory …………….................................27

Validity of Kolb's 1985 Learning Style Inventory ....................................................28

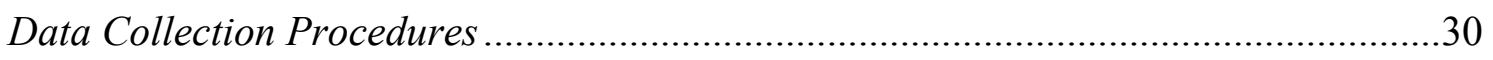

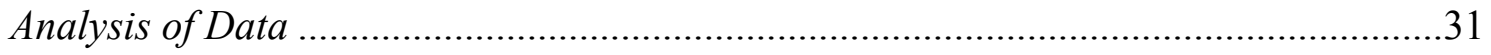

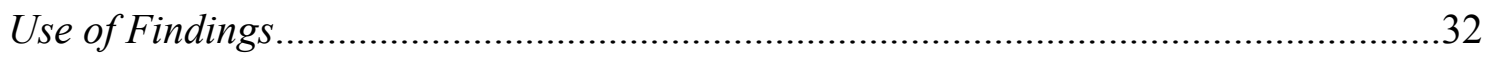

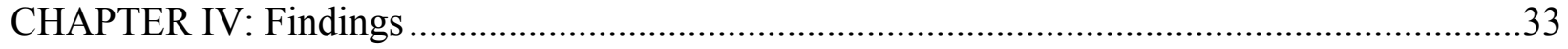

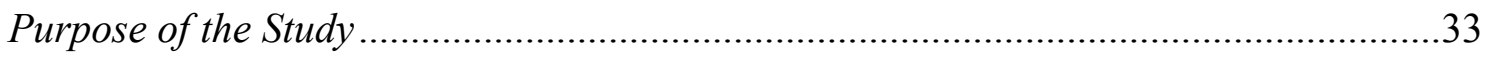

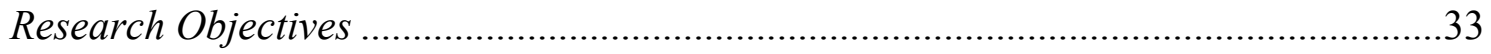

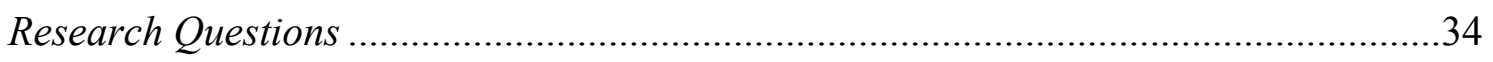

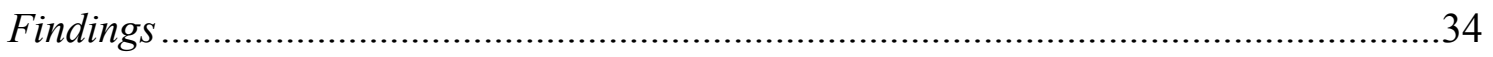

CHAPTER V: Summary, Conclusions and Recommendations..................................................48

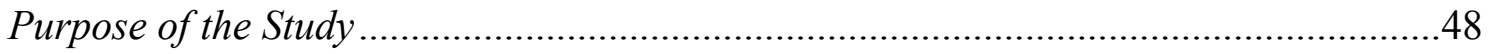

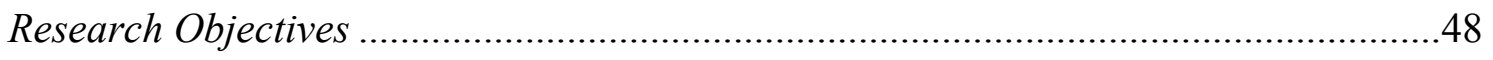


Research Questions

Summary

Summary of Demographic Information .50

Summary of Learning Style Determinations .50

Conclusions .50

Recommendations.

REFERENCES

APPENDIX A: Mailing Cover Letter

APPENDIX B: Demographic Survey .61

APPENDIX C: Follow-up Letter .63

VITA .65 


\section{LIST OF TABLES}

Table 1: Distribution of the Number of Years of Extension Experience of Agents

Responsible for Pesticide Re-Certification Programs in West Virginia

Table 2: Distribution of the Gender of Agents Responsible for Pesticide ReCertification Programs in West Virginia .36

Table 3: Distribution of the Area of Study of the Bachelors Degree of Agents

Responsible for Pesticide Re-Certification Programs in West Virginia

Table 4: Distribution of the Area of Study of the Master's Degree of Agents

Responsible for Pesticide Re-Certification Programs in West Virginia.

Table 5: Distribution of the Age of Agents Responsible for Pesticide Re-

Certification Programs in West Virginia

Table 6: Distribution of the Major Program Area of Agents Responsible for

Pesticide Re-Certification Programs in West Virginia.

Table 7: Distribution of Learning Styles of Agents Responsible for Pesticide Re-

Certification Programs in West Virginia

Table 8: Comparison of the Learning Style with Years of Extension Experience of Extension Agents Responsible for Pesticide Re-Certification Programs in West Virginia

Table 9: Comparison of the Learning Style of Extension Agents Responsible for Pesticide Re-Certification Programs in West Virginia with their Major Program Area

Table 10: Comparison of the Learning Style of Agents Responsible for Pesticide Re-Certification Programs in West Virginia with their Gender.

Table 11: Comparison of the Learning Style of Extension Agents Responsible for Pesticide Re-Certification Programs in West Virginia with the Study Area of their Bachelor Degree.

Table 12: Comparison of the Learning Style of Agents Responsible for Pesticide Re-Certification Programs in West Virginia with the Study Area of their Master's Degree.

Table 13: Comparison of the Learning Style of Extension Agents Responsible for Pesticide Re-Certification Programs in West Virginia with their Age. 


\section{LIST OF FIGURES}

Figure 1: Kolb's Theory of Experiential Learning ....................................................................16

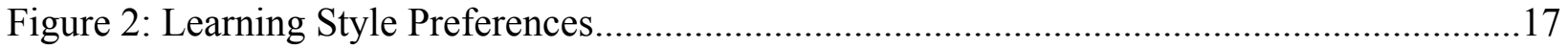




\section{CHAPTER I}

\section{Introduction}

Extension education has been a source of working knowledge for many adults living in rural settings. Rural communities depend on Extension agents for information concerning all aspects of living. Adults often attend programs where the objective of the program is for them to utilize new methods and ideas. The land grant system was created to disseminate new methods and ideas to the public. The Morrill Acts of 1862 and 1890 created the land grant institution system whose purpose was to provide a broad range of people "with a practical education that had direct relevance to their daily lives" (NASULGC, 1995). Later in 1914, the Smith-Lever Act created the Cooperative Extension Service to associate with each land grant institution. Information from research was then disseminated to the public through Extension agents (NASULGC, 1995). The purpose of the land grant system as stated in the Morrill Act of 1862 was:

...the endowment, support, and maintenance of at least one college where the leading object shall be, without excluding other scientific and classical studies, and including military tactics, to teach such branches of learning as are related to agriculture and the mechanical arts, in such manner as the legislatures of the states may respectively prescribe, in order to promote the liberal and practical education of the industrial classes in the several pursuits and professions in life. (The Morrill Act of 1862, reproduced in NASULGC, 1995) 
West Virginia University (WVU) is an example of land grant institution within the State of West Virginia. The WVU Extension Service provides many learning opportunities to people living in West Virginia. Their mission is:

...to form learning partnerships with the people of West Virginia to enable them to improve their lives and communities. To these partnerships, we bring useful research and experienced based knowledge that facilitates critical thinking and skill development. (WVU Extension Service, 2004) Pesticide re-certification is an example of Extension programs through which the WVU Extension Service distributes "useful research and experienced based knowledge" to the people of West Virginia. Individuals who apply pesticides are required by law to obtain a license to be a certified applicator to purchase and apply restricted use pesticides. These individuals are also required to obtain continuing education units (CEUs) that count towards the renewal of their private applicator's license through training programs that educate the proper use and handling of pesticides. They are expected to use the information in everyday farm management (West Virginia Legislative Rule, Ch.19-16A). These programs provide learning opportunities for the individuals renewing the pesticide license, as well as opportunities for Extension agents to develop learning environments that satisfy the needs of the clients in their community. As a result, research has been conducted on many topics related to adult education. The main focus in recent years has been learning styles of Extension agents planning programs that involve adult learning.

\section{Background and Setting}

Pesticide regulations, either state or federal are not new. The first pesticide law was adopted by the state of New York in 1898. It regulated the sale of Paris green, the most 
important insecticide in use at the time. Before this law, if regulated at all, pesticides were addressed under drug laws. Federal legislation aimed at regulating insecticides and fungicides were not initiated until the early 1900 s.

Two types of pesticide regulations existed early on; those concerned with residues or adulteration of food by use of pesticides, and those concerned with the registration of pesticides to protect the purchaser from substandard and fraudulent products. The Pure Food and Drug Act regulated the first type federally in 1906 (United States Statutes at Large ( $59^{\text {th }}$ Cong., Sess. I, Chp. 3915, p. 768-772). The Insecticide Act of 1910 was passed "to protect farmers from adulterated or misbranded pesticide products" (U. S. Environmental Protection Agency, 2004). Later on, these regulations were replaced by the Federal Food, Drug and Cosmetic Act of 1938 and the Federal Insecticide, Fungicide and Rodenticide Act (FIFRA) of 1947 (U.S. Environmental Protection Agency, 2004). These laws have been revised through amendment many times. The user of pesticides, the hazard to other farm workers and the protection of the environment were not regulated at the federal level prior to 1972 and passage of the Federal Environmental Pesticide Control Act amending FIFRA (U.S. Environmental Protection Agency, 2004).

The Federal Environmental Pesticide Control Act, a major amendment of FIFRA, was enacted by Congress and signed into law on October 12, 1972. The Act included many new major provisions and became the responsibility of the Environmental Protection Agency. In addition to regulations concerning registrations and residues that may exist in our food, it created new provisions. Those provisions of primary interest that affect the use and user of the pesticide include: the classification of first time pesticides and their uses as general or restricted use, certification of users of restricted pesticides as private or commercial applicators, pesticide use 
inconsistent with labeling, and authorization of cooperation with the states in training and certification of an applicator. The act also regulated the use of all pesticides and extended federal pesticide regulations within each state so that all had to meet the minimum standards set by federal regulations under the amendment. Re-entry intervals to protect agricultural workers are a part of the regulations although not specifically mentioned in the act. Other provisions include the registration of all pesticides by the Environmental Protection Agency (EPA), whether they move within or between states, thus controlling their distribution and sale, data requirements for registration, registration and inspection of establishments, experimental use permits, penalties, disposal and storage, and monitoring. (U.S. Environmental Protection Agency, 2004)

An effort has been made by states nationwide, in cooperation with the United States Cooperative Extension Service, to promote the proper use of pesticides as well as reduce the reliance on chemicals for pest control. As a result of Federal Environmental Pesticide Control Act of 1972 and subsequent amendments, states have passed their own legislation to regulate pesticides. West Virginia passed their legislation in 1990. The objective of the West Virginia Pesticide Control Act of 1990 is to:

...regulate and control pesticides in the public interest, by their registration, use and application. The Legislature finds that pesticides perform a vital function in modern society because they control insects, fungi, nematodes, rodents and other pests which ravage and destroy our food and fiber, which serve as vectors of disease, and which otherwise constitute a nuisance in the environment or the home; they control weeds which compete in the production of foods and fiber, disrupt the supply of energy, render highways 
unsafe and which otherwise are unwanted elements in our environment; and they regulate plant growth to enhance both the quality and quantity of our food and fiber and to facilitate its harvest. Pesticides, however, may be rendered ineffective, may cause injury to man or may cause unreasonable, adverse effects on the environment if not properly used. They may injure man or animals either by direct poisoning or by the gradual accumulation of pesticide residues in their tissues. Crops or other plants may be affected by their improper use. The misapplication, drifting or washing of pesticides into streams or lakes may cause appreciable damage to aquatic life. A pesticide applied for the purpose of killing pests in a crop, which is not itself injured by the pesticide, may drift and injure other crops or nontarget organisms with which it comes in contact. Therefore, it is deemed necessary to provide for the control of pesticides. (West Virginia Legislative Rule, Ch. 19, section 16A-2)

The West Virginia Pesticide Control Act of 1990 provides requirements for private use applicators to obtain and maintain certification to use restricted-use pesticides. As a condition to renew their pesticide license, applicators are required to accumulate five hours or 10 continuing education units (CEUs) over a three-year period. The West Virginia University (WVU) Extension Service works in cooperation with the State of West Virginia to provide programs that will help individuals earn credit toward license renewal. The purpose of these programs is to promote environmental and personal safety as well as educate pesticide applicators (West Virginia Control Act. 19-16A. Section 7.1 and 7.3). 
In West Virginia, pesticide applicator re-certification programs must meet certain criteria before individuals can attend and earn credit. The programs must be open to the public as well as be non-discriminatory. The Extension agent offering the program must submit a final written agenda to the Pesticide Regulatory Programs office within 30 days of the program date (Guidelines for Pesticide Re-certification Training Programs, 1992). The agenda must contain the address and telephone number of the person submitting the program; the program curriculum, proposed speakers and their qualifications; the location, date, starting time, breaks, and ending time of the program; time allowed for each speaker; and the number of West Virginia applicators who may attend (Guidelines for Pesticide Re-Certification Training Programs, 1992). The West Virginia Department of Agriculture (WVDA) must make copies of the training materials available for program review. The WVDA may audit these programs when it is deemed necessary (Guidelines for Pesticide Re-Certification Training Programs, 1992).

Pesticide re-certification training programs aim at educating pesticide applicators on the proper use and safety of pesticide application. A certified pesticide applicator must have a practical knowledge of pest control practices. The practical knowledge includes being able to recognize common pests and their damage; read and understand pesticide container labeling; and possess a basic knowledge of pesticide safety precautions, disposal procedures, and related information. Other topics that are considered appropriate for program curriculum include applicable state and federal laws and regulations; application techniques; pesticide waste disposal; environmental concerns; worker protection and safety; pests and pesticides; new developments; and IPM concepts. (Guidelines for Pesticide Re-Certification Training Programs, 1992). Programs covering these topics focus on the learning of the material by the adults using restricted-use pesticides. As a result, adult learning is a topic for research. 
Adult learning is an issue that has been addressed by Extension professionals for many years. There are many theories that outline how adults learn through experience. According to M.K. Smith (2001) there are two types of experiential learning. One type of experiential learning involves students who are presented with the opportunity to 'acquire and apply knowledge, skills and feelings in an immediate and relevant setting' (Smith, 2001). Smith points out that this type of experiential learning is characteristic of professional training programs in social work or teaching. Another type of experiential learning is learning brought about by people, not a formal learning institution. Smith (2001) states that learning 'is achieved through reflection upon everyday experience and is the way that most of us do our learning.'

Many theories involving learning through experience provide the basis from which David A. Kolb developed his own Theory of Experiential Learning. One of these influences was Kurt Lewin. Lewin is generally credited as the person who coined the term 'action research'. The research needed for social practice can best be characterized as research for social management or engineering. It is a type of action-research, a comparative research on the conditions and effects of various forms of social action, and research leading to social action. Research that produces nothing but books will not suffice. (Lewin 1946, reproduced in Lewin 1948: 202-3) Lewin developed a series of steps of actions that Kolb used as a basis for the Theory of Experiential Learning. In the first step of Lewin's approach, an individual or organization identified a general idea. Then they would embark on a fact finding mission about the idea. The third step involved planning what action would be taken based upon the reconnaissance information gathered in the previous step. Next, the individual(s) would evaluate the action that was taken. If the action did not fulfill the objective, then the plan would be amended. Lastly, a 
second action would be taken (Lewin, 1948). An action approach to research is focused on problem-solving in social and organizational environments that parallels Dewey's idea of learning from experience (Smith, 2001).

Another source of influence in the development of Kolb's Theory of Experiential Learning was John Dewey. Dewey developed his theory of knowledge in opposition to an accepted view of how humans obtained knowledge from their environment. Traditionalists of the time viewed human thought as "a subjective primitive out of which knowledge was composed" (Field, 2001). Dewey viewed thought as a result of an organism interacting with its environment. Knowledge played an instrumental role in guiding and controlling the organism's interaction with its surroundings (Field, 2001). In his view, an organism interacts with its surroundings "through self-guided activity that coordinates and integrates sensory and motor responses" (Field, 2001). As a result, Dewey argued that the world is not passively perceived. Organisms actively engage in the manipulating their environment through the processes of inquiry and learning (Field, 2001). Dewey described three phases involved in the process of inquiry. The process begins with the 'problematic situation.' In this instance, instinctive responses of a human to environmental stimuli "are inadequate for the continuation of ongoing activity in pursuit of the fulfillment of needs and desires" (Field, 2001). Dewey emphasized in many of his writings "that the uncertainty of the problematic situation is not inherently cognitive, but practical and existential" (Field, 2001). Field (2001) describes the last phases of the process of inquiry in the following manner:

The second phase of the process involves the isolation of the data or subject matter which defines the parameters within which the reconstruction of the initiating situation must be addressed. In the third, reflective phase of the 
process, the cognitive elements of inquiry (ideas, suppositions, theories, etc.) are entertained as hypothetical solutions to the originating impediment of the problematic situation, the implications of which are pursued in the abstract. The final test of the adequacy of these solutions comes with their employment in action. If a reconstruction of the antecedent situation conducive to fluid activity is achieved, then the solution no longer retains the character of the hypothetical that marks cognitive thought; rather, it becomes a part of the existential circumstances of human life.

Though not specifically drawn upon in the development of Kolb's Theory of Experiential Learning, the research of E.L. Thorndike has some relevance to the process of experiential learning. Thorndike conducted many experiments on the mental capacities of animals, such as cats and dogs. He believed that an animal's mental life (his term) consisted of sensory capacity, instinctive behavior, and reactions based on experience (Lattal, 1998). Thorndike focused on animal reactions resulting from experience. He suggested that these reactions are a result of "ordinary associative processes without aid from abstract, conceptual, inferential thinking" (Thorndike, 1898, p.1). Thorndike placed association between instinctive behavior and reasoning on a continuum of thought processes. He had two purposes for conducting his research. Thorndike aimed "to provide experimental evidence in support of an account of animal behavior based on a combination of instinctive behavior and ordinary associative processes, without invoking reasoning into the explanation of such behavior..."(Lattal, 1998). The second reason for his research was to gain a better understanding of the development of human mental life by tracing thought processes back to its origin (Lattal, 1998). He was interested in the evolution of the mind which he defined as "the sum of 
connections between situations which life offers and the responses which man makes" (cited from Joncich, 1962, p. 11 by O’Donnell, 1985, p. 227).

Thorndike conducted research on the behavior processes of animals and was the first of his predecessors to ask if similar behavioral processes are involved in the control of problem solving in animals as in humans (Lattal, 1998). Thorndike asked if "animal association is homologous with the association of human psychology" (1898, p. 108). According to Lattal (1998), "homologous was drawn from evolutionary biology, where homologous structures are those with similar phylogenetic origin (e.g. the wing of a bird and the foreleg of a horse) despite different function (e.g. walking and flying)" (p. 328). Homologous is contrast to analogous structures, which have different phylogenetic origins but similar functions (Lattal, 1998). In psychology, homologous and analogous have similar meanings to their evolutionary biological meanings. Homologous refers to "different response classes controlled by the same process despite physical differences in the response class" (Lattal, 1998, p. 328) and analogous describes "response classes that appear to be similar despite their different controlling mechanisms" (Lattal, 1998, p. 328). Thorndike was one of the first to inquire if different appearing behavior patterns have common origins. He hoped to discover homologous thought processes in animal intelligence. If he found these processes, he could conclude that a difference in intelligence was due to the difference in degree, not in kind. Thordike consistently found, through systematic replication, that the animals in experiments learned most often through trial and error, not through reasoning and imitation. He concluded that there were essential differences between animal and human behavior. However, Thorndike did point out that the principles of trial and error learning may be a good method of understanding human behavior. (Lattal, 1998) 
Knowing how adults prefer to learn is an important component in the program planning process. Planning a program by selecting teaching methods that will allow adults to learn through the style they prefer will increase the learner's ability to grasp and use information that is being presented. Educational research has found that adults learn most effectively through experience (Caffarella \& Barnett, 1994). Active learning allows adults to construct meaning and deep understanding instead of aimless recording of knowledge. When compared to traditional methods, experiential learning helps to develop and strengthen the bond between the learner and what is being taught. (Caffarella \& Barnett, 1994)

\section{Statement of the Problem}

Adult learning has been the focus of research studies in the field of Extension for many years. Identifying the learning styles of adults participating in Extension educational programs has been conducted by some researchers so that the most conducive learning environment can be created. However, research concerning relationships between an adult's learning style and their basic demographic information has been limited.

\section{Purpose of the Study}

The purpose of this study was to determine the learning style preferences of Extension agents responsible for pesticide re-certification training programs in West Virginia. The information may be helpful in improving the learning environments of private pesticide applicators in West Virginia. By using the theories of Kolb, this study proposed a method of determining learning styles and discovering relationships that may exist between the agents' learning style and their basic demographic information. An identification of agents' learning styles has implications for their teaching styles and the way they interact with clients. The information may help Extension agents provide more effective learning environments to their 
adult clientele as well as help provide insight to the effectiveness of the pesticide re-certification training program in West Virginia.

\section{Research Objectives}

The following objectives were answered:

1. Categorize Extension agents in West Virginia as diverger, assimilator, converger, or accommodator depending on their scores on Kolb's Learning Style Inventory (LSI).

2. Determine if a correlation exists between the agents' learning style and the agents' primary program area.

3. Determine if a correlation exists between the Extension agents' learning style and the number of years of Extensions experience.

4. Determine if a correlation exists between the Extension agents' learning style and their gender.

5. Determine if a correlation exists between the Extension agents' learning style and their age.

6. Determine if a correlation exists between the Extension agents' learning style and the area they earned their Bachelor degree.

7. Determine if a correlation exists between the Extension agents' learning style and the area they earned their Master's degree.

\section{Research Questions}

The following research questions were answered during this study:

1. What were the learning styles of Extension agents that teach pesticide re-certification training programs in West Virginia? 
2. Were there relationships that exist between an Extension agent's learning style and their years of Extension experience, program area, gender, area of study of their Bachelor and Master's degrees and age?

3. If these relationships exist, can these factors offer the probability of learning style preference?

\section{Limitations of the Study}

This study is limited to Extension agents that conducted pesticide re-certification training programs in West Virginia during the time-period of January 1, 2000 to April 30, 2000. 


\section{CHAPTER II}

\section{Review of Literature}

Adults living in rural settings depend on Extension educators for information related to many aspects of their lives. One program that assists adults in crop management is the pesticide re-certification training program. Private pesticide applicators are required to attend programs to allow them to accumulate 10 CEUs over a 3-year period. The CEUs allow these individuals to renew their pesticide license in order to buy and apply restricted-use pesticides. The educational programs are designed to increase practical knowledge about pesticide application and address environmental issues related to agriculture production. (Guidelines for Pesticide Re-Certification Training Programs, 1992)

Adults have different learning styles than children. Knowles theory of andragogy differentiates adults learning from the way children learn (Atherton, 2003). As outlined by Cantor (1992, p. 36-37) and Cranton (1992, p. 13-14, 49), adults have prior knowledge and life experiences; autonomous and self directed; goal oriented; relevancy oriented; and are practical, as well as problem solvers in the learning process. Adults are more likely to rely on their prior knowledge as well as act as resources for others during the learning process. They also integrate their learning experiences into their value and belief system, which explains why adults make a deep investment when they learn (Caffarella \& Barnett, 1994). Adults also have different barriers to learning than children. These include responsibilities; lack of time, money and child care; scheduling problems; transportation problems; insufficient confidence; and being in circumstances where learning is a necessity even though the adult has no interest. (Cantor, 1992, p. 39) 
Kolb's Theory of Experiential Learning

During the 1980’s, David A. Kolb presented his Theory of Experiential Learning. In his theory, a four state continuous cyclical process characterizes effective learning. The four states are experience, observation, reflection, and assimilation. Learning can start at any of the stages of the cycle; however, Kolb suggests that the learning process begins most frequently with action, with the person seeing the effect of the action in that particular situation (Smith, 2001). Experience is translated into concepts that can be used to guide the choice of new experiences. Immediate experience is the basis for observation and reflection. Observation and reflection is where concepts are assimilated and actively tested. Testing gives rise to a new concrete experience (Kolb, 1984). According to Smith (2001), if learning has occurred, the process should be viewed as spiral. The person is then able to apply the action in a new circumstance within the range of generalization. As a result, the person is able to anticipate possible effects of the action (Smith, 2001) (see Figure 1).

Concrete Experience. A high score in Concrete Experience represents a receptive experienced-based approach to learning that depends on feelings-based judgments. Theoretical approaches are considered to be unhelpful to learners who score high in Concrete Experience. These learners acquire knowledge best from specific examples in which they can be involved. They also have a tendency to relate better to peers than to authority (Kolb, 1984).

Abstract Conceptualization. A learner who scores high in abstract conceptualization tends to prefer an analytical, conceptual approach to learning. They rely heavily on logical thinking and rational evaluation. These learners are oriented toward things and symbols than towards other people. Learning is best achieved in authority-directed, formal learning situations 
than emphasize theory and systematic analysis. Often, these learners are frustrated when left to "discover learning" approaches because of their lack of structure (Kolb, 1984).

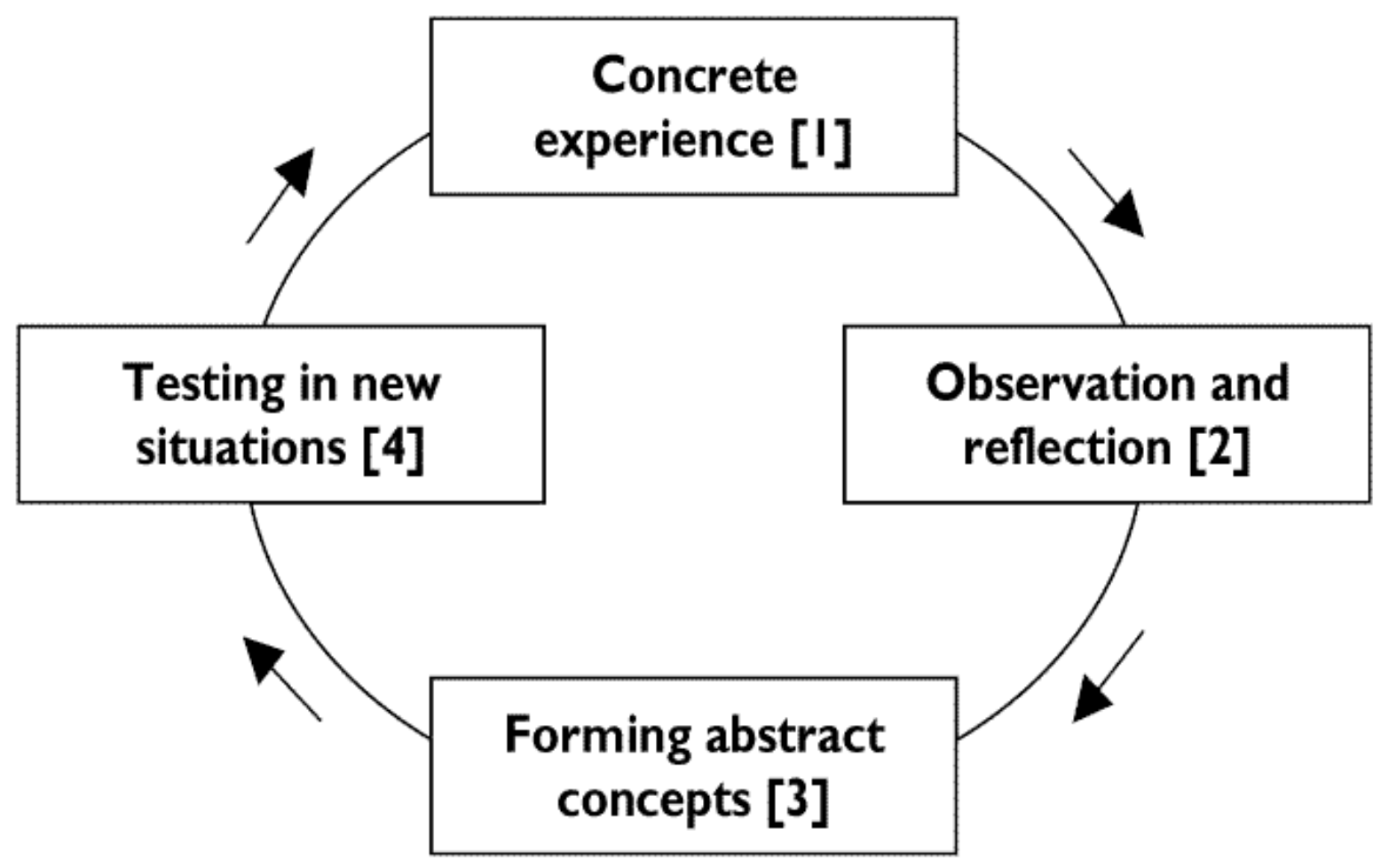

Figure 1. Kolb's Theory of Experiential Learning

Reflective Observation. Learners who prefer to learn through reflective observation tend to rely heavily on careful observation in making judgments. They take a tentative and impartial approach to learning. These learners are most comfortable in lecture situations that allow them to be an impartial objective observer. These learners tend to be introverts (Kolb, 1984).

Active Experimentation. A high score in active experimentation shows that the individual prefers learning through "doing." These learners rely heavily on experimentation. Teaching activities that offer the best learning environments are projects, homework or group discussions. Learning situations such as lectures are very unfavorable with these learners. Most tend to be extroverts (Kolb, 1984). 
Kolb defined four different learning styles. These four learning styles are divergers, assimilators, convergers and accommodators. Each learning style combines two steps in the learning cycle (see Figure 2).

\section{Concrete Experiencing (CE)}

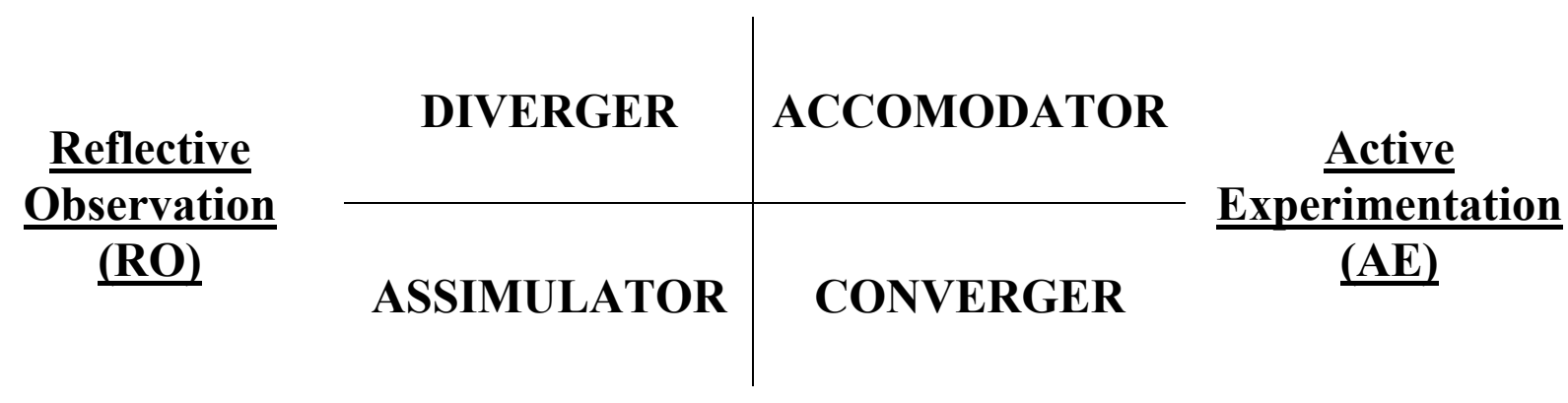

\section{$\underline{\text { Abstract Conceptualizing (AC) }}$}

Figure 2. Learning Style Preferences

Diverger. A diverger is well suited for concrete experience and reflective observation. They are interested in people and emotional elements. They have a strong imaginative ability. These learners have broad cultural interests and tend to specialize in the arts. The diverger style of learning is characteristic of individuals from humanities and liberal arts backgrounds. Learners with this learning style often become counselors, organizational development specialists, and personnel managers (Kolb, 1984).

Assimilator. Learners of this learning style are characterized by their ability to create theoretical models. They learn best in environments that include abstract conceptualization and reflective observation. They are not interested in people and practical applications of knowledge. More often than not, they are concerned about abstract concepts. These learners are 
typically found in research and planning departments. The assimilator learning style is characteristic of basic science and mathematics (Kolb, 1984).

Converger. These learners learn best in environments that include abstract conceptualization and active experimentation. Their greatest strength lies in the practical application of an idea. They prefer to deal with things rather than people. Convergers tend to have narrow technical interests and often choose to specialize in physical sciences (Kolb, 1984).

Accommodator. Accommodators are best at concrete experience and active experimentation. They involve themselves in doing things and finding new experiences. They are called accommodators because they succeed in adapting to specific immediate circumstances. Problem solving is an intuitive trait. Accommodators have the ability to work easily with people, but are sometimes perceived as pushy. Their career interests include marketing and sales. They often have an educational background in technical or practical fields (Kolb, 1984).

Studies using Kolb's Learning Style Inventory

A few Extension professionals have utilized Kolb's Theory of Experiential Learning in researching topics in Extension education. A study by Rollins and Yoder (1993) utilized the instrument Kolb created. In the study, 211 cooperative Extension county staff of Pennsylvania completed the Learning Style Inventory (LSI). The study found that agriculture agents were identified most frequently as an Assimilator or a Converger. County directors were split evenly among Converger, Accommodator, and Assimilator. Family living and 4-H youth professionals were most frequently found to be Accommodators. What Rollins and Yoder concluded from the results were that all four groups in the study preferred to learn by doing. These agents preferred a learning environment where the educator shows the learner how to do what is being taught. 
A similar study by Park and Gamon (1996) examined the role of learning styles in computer training programs. The subjects were a random sample of 200 Extension personnel employed by the Iowa State University Extension Service. The respondents were asked to complete a commercial learning style inventory and a researcher generated questionnaire. Park and Gamon found that $29 \%$ of the respondents were identified as a converger learning style, $26 \%$ were identified as diverger, $25 \%$ were identified as accommodator, and $20 \%$ as assimilator. No specific style was dominant. Park and Gamon concluded that a variety of teaching methods should be utilized when delivering computer-training programs to Extension personnel in Iowa. They also suggested that because professional staff had a tendency to lean toward converger learning styles, opportunity to experiment should be given to program participants.

Joerger and Persons (1993) researched the cognitive abilities, dimensions, and styles of farm business management (FBM) educators of Minnesota, using Kolb’s Learning Style Inventory. They found that FBM educators indicated a preference to apply ideas to real-life situations (active experimentation), followed solving situations through the creation of systematic plans and ideas (abstract conceptualization). FBM educators least preferred learning situations where they gain information through interaction with other people (concrete experience). The researchers also found that FBM educators prefer to perceive new information through thinking processes as opposed to feeling strategies. They found that FBM educators preferred to directly apply information to real-life problems as opposed to reflecting on the information and converting it into knowledge. The dominant learning style of the FBM educators was converger. Joerger and Persons concluded from the study that FBM educators were primarily convergers and assimilators, who indicated a preference for receiving information through abstract means. 
Rollins and Yoder (1992), in another study, identified learning style preferences of Extension agents and examined relationships between learning style preferences and variables related to assignments. Agricultural agents and county directors preferred the converger learning style. The total staff preferred assimilator learning style the least. The accommodator learning style was the second most-preferred style (27\%). Rollins and Yoder recommended that adult educators incorporate the students learning style into their style of teaching. Learning styles of individuals need to be incorporated in a meaningful manner to enhance the organization's effectiveness.

\section{Studies of Adult Learner Comprehension}

Researchers have focused on discovering learning methods by which adults prefer to gain knowledge. A study by Okoro and Miller (1994) focused on the comprehension level of instructors teaching the Pesticide Re-Certification Training Programs. In the study, research factors related to the learning of participants in the Ohio Pesticide Private Applicator's Training Program were examined. The four levels of cognition were used in Bloom's Taxonomy, modified by Newcomb and Trefz (1987) are remembering, processing, creating, and evaluation. Remembering level responses included recollection of basic facts taught during the training program to pass certification. Knowing the health protection regulations was also included in the remembering level responses. Processing level responses were defined as having the ability to understand and adopt first aid steps as well as being able to apply basic principles of dealing with pesticide drift. The creating level required the ability to detect pesticide use. Understanding how the program helped reduce the cost of pesticide application was considered evaluation level response. 
Okoro and Miller (1994) concluded from the information gathered that the most frequent intended level of instruction was at the remembering level of cognition. At this level, participants were able to achieve the most. Prior knowledge was found to be important. A very strong inverse relationship was found between the learning of participants and their prior knowledge of pesticide application. The results of this study indicated that agents presenting the information on pesticide application often do not have a hands-on approach to learning about pesticide application practices.

Bhardwaj and Miller (1993) investigated the cognition levels of county agricultural Extension agents who plan and carry out programs. The study looked at the attitude of county agents toward a classification system of educational objectives, the cognitive levels of the instruction offered by the county agricultural agents, and how the cognition levels of instruction vary with agent's age, work experience and support staff use.

Bhardwaj and Miller (1993) found that most of the programs (30\%) were delivered at the remembering and processing level, followed by remembering $(25 \%)$. Researchers also discovered that agents found educational objectives classification most useful for program evaluation as well as for program planning. Though agents responded positively to the objectives classification system, none of those interviewed developed a formal written lesson plan. Agents briefly outlined how they planned to conduct the program. When objectives were developed, they were not formulated in terms of performance and end result or behavior. Bhardwaj and Miller concluded from the study that agents who possess a more positive attitude toward the usefulness of educational objectives had the tendency to offer their programs at higher cognitive levels. Agents whose focus was crop science related programs had less positive attitudes toward the use of education objectives than did agents whose focus was animal/dairy science related 
programs. They also found that agents who use more resource persons in their program tend to have less positive attitudes toward the use of a classification system. Older agents and more experienced agents tend to have more positive attitudes toward an education objective development classification system.

Miller and Ismail (1993) researched the intended and actual levels of cognition in instructional programs offered county agricultural Extension agents and state agricultural specialists. The population of the study was county agriculture Extension agents and state agricultural specialists. There were three methods of data collection. They were audio taping, interviews, and questionnaires. Miller and Ismail found that the highest intended level of cognition was analysis while the highest actual level of cognition was between analysis and synthesis. Agriculture agents were found to deliver programs above the analysis level. The average actual level of cognition delivered by state agricultural specialists was near the synthesis. Miller and Ismail found that the area of degree influenced the level of intended cognition. County agricultural agents and state agricultural specialists, whose degree area was in a technical field of study, delivered programs at a higher intended level of cognition than did agents and state specialists whose degree was in a social science. A negative moderate association was indicated between the highest intended level of cognition and years experience. When the number of years of service increased, the highest intended level of cognition tended to decrease. Miller and Ismail also found that the higher the degree completed, the higher the highest intended level of cognition. They recommended agricultural agents and state specialists should focus on planning and delivering programs at higher levels of cognition. Agents and specialists should also attend workshops to familiarize themselves with the use of educational objectives. 
Studies Concerning Methods of Program Delivery

Additional studies have not used a specific instrument developed from a theory but have researched methods of delivering Extension educational programs. Richardson (1994) interviewed clientele from 11 North Carolina counties. They were asked to identify the methods through which they preferred to learn. They were given the choices of hearing, seeing, touching/feeling, smelling and discussing. Slightly over $70 \%$ of the clientele preferred to learn by "doing". When asked what combination of learning methods they preferred, clientele stated they preferred any combination that involved "doing."

The same questions were presented to new agents at a North Carolina new employee orientation in 1992. The results were consistent with the clientele study. Slightly over $80 \%$ of the new Extension agents preferred to learn by "doing." These agents also preferred to learn through any combination that involves "doing." The most preferred combination of learning methods was "seeing/doing/discussing." Richardson concluded that Extension education programs should include opportunities for experiential learning.

Richardson (1995) researched preferred information delivery methods of farm clientele in North Carolina. Richardson found that Extension clientele preferred to receive information through personal visits, meetings, newsletter, method demonstrations, and workshops. When asked why these methods of delivery were most preferred, clientele placed considerable value on them because they offered opportunity to see, do, and discuss. These methods also provided clientele with an opportunity to receive information that was subject and audience specific as well as providing them opportunity to receive information "in an understandable and personally comfortable manner." 
Trede and Whitaker (1998) studied the educational needs of new farmers in Iowa. All of the respondents were male with 14 years of formal education. The predominant enterprises were crops, swine and beef cattle. Trede and Whitaker developed an instrument that inquired about the current and future usefulness of educational providers and the delivery methods of beginning farmer education. These beginning farmers expressed a strong interest in experiential learning, production agriculture skill development and a hands-on approach to problem solving. They also agreed that critical thinking should be included in problem-solving situations. It was also suggested that Extension educators utilize a variety of teaching methods. Beginning farmers thought that a variety of learning sources should be used to solve farm management problems. They liked having on-site instruction, single-issue meetings and contacting public institutions for unbiased information.

Teaching methods and the classroom environment are important components in the learning process. Theoretically, if the teacher's method of teaching matches the learning style of the learner, then learning can be optimized. It is important for the educator to be aware of students' learning styles so the learning environment can fulfill its maximum potential. It has been found that active participation in the learning process connects the learner to material being learned. Learning them becomes the responsibility and sole ownership of the learner. 


\section{CHAPTER III}

\section{Methodology}

\section{Purpose of the Study}

The purpose of this study was to determine the learning style preferences of Extension agents responsible for pesticide re-certification training programs in West Virginia. The information may be helpful in improving the learning environments of private pesticide applicators in West Virginia. By using the theories of Kolb, this study proposed a method of determining learning styles and discovering relationships that may exist between the agents' learning style and their basic demographic information. An identification of agents' learning styles has implications for their teaching styles and the way they interact with clients. The information may help Extension agents provide more effective learning environments to their adult clientele as well as help provide insight to the effectiveness of the pesticide re-certification training program in West Virginia.

\section{Research Objectives}

The following objectives were answered:

1. Categorize Extension agents in West Virginia as diverger, assimilator, converger, or accommodator depending on their scores on Kolb's Learning Style Inventory (LSI).

2. Determine if a correlation exists between the agents' learning style and the agents' primary program area.

3. Determine if a correlation exists between the Extension agents' learning style and the number of years of Extensions experience.

4. Determine if a correlation exists between the Extension agents' learning style and their gender. 
5. Determine if a correlation exists between the Extension agents' learning style and their age.

6. Determine if a correlation exists between the Extension agents' learning style and the area they earned their Bachelor degree.

7. Determine if a correlation exists between the Extension agents' learning style and the area they earned their Master's degree.

\section{Research Questions}

The following research questions were answered during this study:

1. What were the learning styles of Extension agents that teach pesticide re-certification training programs in West Virginia?

2. Were there relationships that exist between an Extension agent's learning style and their years of Extension experience, program area, gender, area of study of their Bachelor and Master's degrees and age?

3. If these relationships exist, can these factors offer the probability of learning style preference?

\section{Research Design}

A descriptive research design was selected to collect the data necessary to answer the research questions. Ary, Jacobs, and Razavieh (1996) define descriptive educational research as: ...the way in which one acquires dependable and useful information about the educative process. Its goal is to discover general principles or interpretations of behavior that can be used to explain, predict, and control events in educational situations - in other words, to formulate scientific theory (p. 20-21).” 


\section{The Population}

The target population consisted of Extension service personnel of West Virginia whose responsibilities include planning and implementing pesticide re-certification training programs $(\mathrm{n}=48)$. The population was selected from the WVU Cooperative Extension Service Personnel Directory. Agents whose program responsibilities included agriculture were targeted for the population of the study. Frame error was minimized since specific information about the agent's program responsibilities was available to the researcher. Two respondents were excluded from the study. One agent no longer was employed with the WVU Extension Service and the other respondent did not have program responsibilities in pesticide re-certification.

\section{Instrumentation}

Each Extension agent received a Kolb’s Learning Style Inventory (LSI) (Kolb, 1985) and a demographic survey through the mail. They completed the LSI and return it. Calculation and graphing of the LSI was done by the researcher. The demographic survey was developed by the researcher and asked the Extension agents to select the range of years in Extension, select their major program area, gender, area of study of the Bachelor and Master's Degree and their age range.

\section{Reliability of Kolb's 1985 Learning Style Inventory (LSI)}

Ruble and Stout (1994) analyzed the internal consistency of the 1985 version of Kolb's LSI. They found an increase in the internal consistency of the instrument but determined this increase was due mainly to the doubling of the number of items from six to twelve and responseset bias of the single-scale-per-column format (Ruble \& Stout, 1994). The user's guide (Kolb, 1985) reports an average alpha coefficient for the four learning abilities scales of .79. However, a meta-analysis of nine independent studies found an average coefficient alpha of approximately 
.82 (Ruble \& Stout, 1994). As stated previously, some consistency is due to a response-set bias, as well as the possibility that the intercorrelations of the ipsative measures inflate the estimates (Ruble \& Stout, 1994). An ipsative scale is the scoring of items of a set where the ranking of three items determines the score of the fourth item.

Ruble and Stout (1994) examined the temporal consistency reliability of the 1985-LSI. Consistency was assessed by examining the test-retest reliability correlations. They found the test-retest reliability coefficients averaged approximately .50. "The proportion of "shared variance" in scale scores between test administrations was on the order of $25 \%\left(.50^{2}\right)$ " (Ruble \& Stout, 1994, p. 34).

Another aspect of reliability that Ruble and Stout (1994) examined was classification stability. Classification stability is a comparison of learning style classifications of an individual measured at different points in time (Ruble \& Stout, 1994). They cited four separate studies, including one of their own, (Sims etal., 1986; Veres etal., 1987; Ruble \& Stout, 1991; Geiger \& Pinto, 1991) where the classification stability was modest at best (Ruble \& Stout, 1994). The classification stability over the four studies averaged $53 \%$. In three of the four studies, the populations consisted of undergraduate business students. The population of the other study was a non-specific student sample (Ruble \& Stout, 1994).

Validity of Kolb's 1985 Learning Style Inventory (LSI)

Studies concerning factor analysis of the 1985 LSI (Geiger et al., 1993; Ruble \& Stout, 1990) have indicated the instrument has validity issues. Factor analysis examines the internal structure of an instrument relevant to the assessment of construct validity (Nunnally \& Burstein, 1994). Kolb (1976b) proposed that his Experiential Learning Model (ELM) consisted of bipolar two-factor structure. Accordingly, factor analysis of the instrument should not extract four 
distinct factors (one for each learning style) but two orthogonal ("non-opposite") factors (one factor for each dimension).

Unless the two bipolar factors are the result of spurious negative intercorrelations caused by ipsative scales, a two factor solution would support two bipolar dimensions of learning proposed by the ELM... (Hwang and Henson, 2002, p. 10)

Ruble and Stout (1990) and Geiger, Boyle and Pinto (1993) conducted similar factor analysis studies on the 1985 LSI. Ruble and Stout (1990) obtained both the two-factor and fourfactor solutions. In the data set analyzed $(n=312)$, the researchers found the following:

(1) for the two-factor solution, AC items and CE items tended to loan as separate factors while the AE and RO items did not generally load on either factor; (2) for the four-factor solution, the $\mathrm{AC}, \mathrm{RO}$ and $\mathrm{AE}$ items tended to load on separate factors, while the CE did not. (Ruble \& Stout, 1994, p. 37) Thus, the factor solutions did not yield the two bipolar dimensions. As a result, the factor analysis failed to support the construct validity of the LSI (Ruble and Stout, 1994)

In another study, Geiger, Boyle and Pinto (1993) administered two versions of the LSI (ipsative format and normative rating format) to 455 business administration students. Both twofactor and four-factor analysis was obtained. The results of the standard (ipsative format) version were similar to those found in Geiger etal. (1992). However, the factor analysis of the normative version failed to support the two bipolar dimensions posited by Kolb's ELM. The two-factor solution showed the $\mathrm{CE}$ items loading together with $\mathrm{RO}$ items. AC items were weighted with $\mathrm{AE}$ items. In the four-factor analysis, only AC items loaded together strongly as a single dimension. 


\section{Data Collection Procedures}

Each agriculture Extension agent received a Kolb’s Learning Style Inventory (LSI) (Kolb, 1985) and a demographic survey through the mail. They completed the LSI and return it. Calculation and graphing of the LSI was done by the researcher. The LSI contains 12 statements that end with a choice of four different responses. The agents were asked to rank these choices on a scale of 4 to 1 , with " 4 " describing how the agent learns best, down to " 1 " for the statement that describes they way the agent least prefers to learn. Each column of responses represented a different aspect of Kolb's Theory of Experiential Learning Cycle. Column 1 described learning through Concrete Experience (CE). Column 2 described learning through Reflective Observation (RO), while columns 3 and 4 described learning through Abstract Conceptualization (AC) and Active Experimentation (AE), respectively. Each column was totaled. Then the total score from the $\mathrm{CE}$ column was subtracted from the total score of the AC column. The total score from RO column was subtracted from the total score of the AE column. The results were two numbers that were plotted on a graph that accompanied the LSI and was provided by the publisher McBer and Company. The four quadrangles consisted of one of each different learning style preference.

\section{Quadrangle}

Upper Left

Upper Right

Lower Left

Lower Right

\section{Learning Style Preference}

Accommodator

Diverger

Converger

Assimilator 
The learning style preference of each respondent was determined by graphing the results of formulas. $\mathrm{AC}$ minus $\mathrm{CE}$ was plotted on the $\mathrm{X}$-axis, while $\mathrm{AE}$ minus $\mathrm{RO}$ was plotted on the $\mathrm{Y}$ axis. The quadrangle that was common to both numbers determined the learning style of that respondent. The demographic survey asked each participant to select the range of years of Extension experience, select their major program area, gender, area of study of the Bachelor and Master's Degree and their age range.

Data collection began March 2, 2000. A follow-up mailing was sent on April 11, 2000 to those agents who had yet to respond to the survey.

Analysis of Data

Descriptive statistics were used to summarize the data. Data were analyzed using Statistical Package for the Social Sciences (SPSS PC+). Cramer's V was used to determine if a relationship exists between Extension agent learning style preference and demographic characteristics such as age, years of Extension service, study area of degrees, gender, and program area. The magnitude of the relationship between learning style and each of demographic factors was determined using Davis' Scale (1971) as follows:

\section{Coefficient}

0.70 or higher $\quad$ Very strong association

0.50 to $0.69 \quad$ Substantial association

0.30 to $0.49 \quad$ Moderate association

0.10 to $0.29 \quad$ Low association

0.01 to $0.09 \quad$ Negligible association 


\section{Use of Findings}

The findings of this study will be used to improve pesticide and pest management training for extension agents in the State of West Virginia. The results will be made available to Extension specialists and personnel of the West Virginia Department of Agriculture responsible

for these training sessions. The results will also be made available to the agents who participated in the study. 


\section{CHAPTER IV}

\section{Findings}

\section{Purpose of the Study}

The purpose of this study was to determine the learning style preferences of Extension agents responsible for pesticide re-certification training programs in West Virginia. The information may be helpful in improving the learning environments of private pesticide applicators in West Virginia. By using the theories of Kolb, this study proposed a method of determining learning styles and discovering relationships that may exist between the agents' learning style and their basic demographic information. An identification of agents' learning styles has implications for their teaching styles and the way they interact with clients. The information may help Extension agents provide more effective learning environments to their adult clientele as well as help provide insight to the effectiveness of the pesticide re-certification training program in West Virginia.

\section{Research Objectives}

The following objectives were answered:

1. Categorize Extension agents in West Virginia as diverger, assimilator, converger, or accommodator depending on their scores on Kolb’s Learning Style Inventory (LSI).

2. Determine if a correlation exists between the agents' learning style and the agents' primary program area.

3. Determine if a correlation exists between the Extension agents' learning style and the number of years of Extensions experience.

4. Determine if a correlation exists between the Extension agents' learning style and their gender. 
5. Determine if a correlation exists between the Extension agents' learning style and their age.

6. Determine if a correlation exists between the Extension agents' learning style and the area they earned their Bachelor degree.

7. Determine if a correlation exists between the Extension agents' learning style and the area they earned their Master's degree.

\section{Research Questions}

The following research questions were answered during this study:

1. What were the learning styles of Extension agents that teach pesticide re-certification training programs in West Virginia?

2. Were there relationships that exist between an Extension agent's learning style and their years of Extension experience, program area, gender, area of study of their Bachelor and Master's degrees and age?

3. If these relationships exist, can these factors offer the probability of learning style preference?

\section{Findings}

In March of 2000, forty-eight (48) extension agents, whose program responsibilities included pesticide re-certification, were mailed Kolb's Learning Style Inventory (LSI) (Kolb, 1985 ) and a questionnaire consisting of a series of questions on demographics characteristics. The demographic characteristics consisted of years of extension service, major program area, Bachelors degree area of study, Master's degree area of study, age, and gender. Kolb's LSI was used to categorize each agent as an assimilator, converger, diverger or accommodator. Thirtyfour (34) of the 48 agents responded to the mailing. Two respondents were excluded from the 
study. One agent no longer was employed with the WVU Extension Service and the other respondent did not have program responsibilities in pesticide re-certification. A response rate of $69.5 \%$ was obtained. Frequencies were calculated on each of the demographic survey questions, as well as the learning styles of the agents participating in the study.

The respondents were asked to use five-year incremental categories to report their years of experience with the Extension service. Both the 6 to 10 and the 20 years or more categories had 12 agents $(37.5 \%)$, respectively. Two categories, 0 to 5 years and 11 to 15 years, had three respondents $(9.4 \%)$ each. Two agents $(6.3 \%)$ stated they had worked for the extension service 16 to 20 years (see Table 1 ).

Table 1

Distribution of the Number of Years of Extension Experience of Agents Responsible for Pesticide Re-certification Programs in West Virginia

\begin{tabular}{lcc}
\hline & $N$ & $\%$ \\
\hline $0-5$ years & 3 & 9.4 \\
$6-10$ years & 12 & 37.5 \\
$11-15$ years & 3 & 9.4 \\
$16-20$ years & 2 & 6.3 \\
$20+$ years & 12 & 37.5 \\
\hline Total & 32 & 100.0 \\
\hline
\end{tabular}

The majority $(n=23,71.9 \%)$ of the respondents were male. Nine $(28.1 \%)$ of the respondents were female (see Table 2). 
Table 2

Distribution of the Gender of Agents Responsible for Pesticide Re-Certification Programs in West Virginia

\begin{tabular}{lcc}
\hline & $N$ & $\%$ \\
\hline Male & 23 & 71.9 \\
Female & 9 & 28.1 \\
\hline Total & 32 & 100.0 \\
\hline
\end{tabular}

Respondents were asked to indicate the area of study for their Bachelor's Degree. They were given the choices of animal science, agricultural education, plant $\&$ soil science, and other. Respondents were asked to write in the area of study for their Bachelor's Degree if they chose "other". An equal number of respondents selected plant \& soil science and other, with 10 respondents (31.3\%) each. Animal science was the next most frequent category with eight (25\%) respondents. The smallest number of agents $(n=4,12.5 \%)$ stated they earned their Bachelor's Degree in the area of agricultural education (see Table 3). These "other" areas of study included English, elementary education, biology, agricultural mechanics, forestry, cinema, chemistry, and home economics.

The respondents were also asked to state the area of study for their Master's Degree. The same choices applied as the area of study for the Bachelor's Degree. The results were similar to the study area of the Bachelor's Degree, in that plant \& soil science and other were selected by 13 respondents (40.6\%) each. Five agents (15.6\%) stated they earned their Master's Degree in animal science, while only one (3.1\%) respondent stated they earned their degree in agricultural education. Included in the category of "other" were study areas of education, adult 
education, communications, agriculture economics, agriculture, counseling, education administration, and entomology (see Table 4).

Table 3

Distribution of the Area of Study of the Bachelors Degree of Agents Responsible for Pesticide Re-certification Programs in West Virginia

N $\%$

\begin{tabular}{lcc}
\hline Animal Science & 8 & 25.0 \\
Agricultural Education & 4 & 12.5 \\
Plant \& Soil Science & 10 & 31.3 \\
Other & 10 & 31.3 \\
\hline Total & 32 & 100.0
\end{tabular}

Table 4

Distribution of the Area of Study of the Master's Degree of Agents Responsible for Pesticide Recertification Programs in West Virginia

N $\%$

\begin{tabular}{lcc}
\hline Animal Science & 5 & 15.6 \\
Agricultural Education & 1 & 3.1 \\
Plant \& Soil Science & 13 & 40.6 \\
Other & 13 & 40.6 \\
\hline Total & 32 & 100.0
\end{tabular}


The agents were asked to indicate their age using ten-year age categories. The age categories were 21 to 30 years, 31 to 40 years, 41 to 50 years and 50 or more years. Fourteen agents $(43.8 \%)$ indicated they were between the ages of 41 and 50 . Nine agents $(28.1 \%)$ were 50 or more years in age. Eight respondents (25\%) were between the ages of 31 to 40 . One agent (3.1\%) was between the ages of 21 and 30 (see Table 5).

Table 5

Distribution of the Age of Agents Responsible for Pesticide Re-Certification Programs in West Virginia

\begin{tabular}{lcc}
\hline & $N$ & $\%$ \\
\hline $21-30$ years & 1 & 3.1 \\
$31-40$ years & 8 & 25.0 \\
$41-50$ years & 14 & 43.8 \\
50 or more & 9 & 28.1 \\
\hline Total & 32 & $100.0 \%$ \\
\hline
\end{tabular}

The agents were asked to disclose the major program area covered in their job responsibilities. They were given the choices of agriculture, 4-H/youth, family \& consumer sciences, and all. Twenty agents (62.5\%) stated their major program area was agriculture. Eight agents $(25.0 \%)$ stated they covered all three program area. Two agents $(6.3 \%)$ stated they covered 4-H/youth. Two agents $(6.3 \%)$ stated their major program area was another area not listed on the survey. They focused on community and economic development (see Table 6). 
Table 6

Distribution of the Major Program Area of Agents Responsible for Pesticide Re-certification

Programs in West Virginia

\begin{tabular}{lcc}
\hline & $N$ & $\%$ \\
\hline Agriculture & 20 & 62.5 \\
4-H/Youth & 2 & 6.3 \\
All & 8 & 25.0 \\
Other & 2 & 6.3 \\
\hline Total & 32 & 100.0 \\
\hline
\end{tabular}

These extension agents were also sent Kolb’s LSI (Kolb, 1985) instrument to complete. Calculation and graphing of the LSI was done by the researcher. The LSI contains 12 statements that end with a choice of four different responses. The agents were asked to rank these endings on a scale of 4 to 1 , with " 4 " describing how the agent learns best and a " 1 " for the statement ending that least likely describes they way they learn. Each column of responses represented a different aspect of Kolb's Theory of Experiential Learning Cycle. Column 1 described learning through concrete experience. Column 2 described learning through reflective observation, while columns 3 and 4 described learning through abstract conceptualization and active experimentation, respectively. The total column score of concrete experience was subtracted from the total column score of abstract conceptualization. The total column score of reflective observation was subtracted the total column score of active experimentation. This resulted in two numbers where the result of abstract conceptualization minus concrete experience represented the $\mathrm{X}$ axis and the result of active experimentation minus reflective observation represented the 
Y axis. These numbers were plotted on a graph that accompanied the LSI and was provided by the publisher McBer and Company. The four quadrangles consisted of a different learning style. The quadrangle that was common to both numbers determined the learning style of that respondent

\section{Quadrangle}

Upper Left

Upper Right

Lower Left

Lower Right

\section{Learning Style}

Accommodator

Diverger

Converger

Assimilator

Converger was the most frequent learning style of the agents participating in the study with 11 respondents (34.4\%). Assimilator and accommodator were the next most frequent learning styles with nine (28.1\%) and seven (21.9\%) respondents, respectively. Diverger was the least frequent learning style among the agents with five respondents (15.6\%) (see Table 7).

Crosstabs were used to compare the years of Extension experience with the learning styles of the agents. Convergers were the dominant learning style overall with eleven (11) agents. Of the 11 agents, four (36.4\%) had 6 - 10 years of Extension experience and four $(36.4 \%)$ had $20+$ years of Extension experience. Two (18.1\%) agents who were convergers had 11 - 15 years of Extension experience, while one (9.1\%) agent had 16 - 20 years of Extension experience. Assimilators were the next most frequent learning style among agents with nine. One agent $(11.1 \%)$ fell in each of the Extension experience categories of $0-5$ years, $6-10$ years and $16-20$ years. Six agents $(66.7 \%)$ had $20+$ years of Extension experience. Seven (7) 
agents were categorized as accommodators. Four of the accommodators $(57.1 \%)$ had $6-10$ years of extension experience, while two (28.6\%) had 0 - 5 years working in Extension. Only one agent (14.3\%) categorized as an assimilator had 20+ years of Extension experience. Agents categorized as divergers included three (60\%) who had worked in Extension for $6-10$ years. One agent each $(20 \%)$ had $11-15$ years and 20+ years working in Extension, respectively (see Table 8).

Table 7

Distribution of Learning Style of Agents Responsible for Pesticide Re-Certification Programs in West Virginia

N $\%$

\begin{tabular}{lcc}
\hline Assimilator & 9 & 28.1 \\
Converger & 11 & 34.4 \\
Accommodator & 7 & 21.9 \\
Diverger & 5 & 15.6 \\
\hline Total & 32 & 100.0
\end{tabular}

A Cramer's V correlational statistic was calculated to determine if a relationship existed between the years of extension experience and their learning style. The association $(0.396)$ between the two factors was not significant at an alpha level of 0.05 .

Crosstabs were used to compare the major program area with the learning styles of the agents. The majority of the agents indicated their major program area was agriculture. Of these agents, seven $(63.6 \%)$ were convergers, five (55.6\%) were assimilators, five $(71.4 \%)$ were accommodators, and three $(60.0 \%)$ were divergers. Of the agents who stated their major program 
area was $4-\mathrm{H} /$ Youth, one agent $(9.1 \%)$ was a converger and the other agent $(14.3 \%)$ was an accommodator. Eight agents indicated their major program area was all three areas, agriculture, 4-H/youth and family/consumer sciences. Of these agents, three (33.3\%) were assimilators, two $(18.2 \%)$ were convergers, one (14.3\%) was an accommodator, and two $(40.0 \%)$ were divergers. Two agents listed their major program area as other. One (11.1\%) of these agents was an assimilator and the other (9.1\%) was a converger (see Table 9). A Cramer's V failed to demonstrate a significant association between these two factors.

Table 8

Contingency Table Comparing the Learning Style of Extension Agents Responsible for Pesticide Re-certification Programs in West Virginia with their Years of Extension Experience

\begin{tabular}{|c|c|c|c|c|c|c|c|c|c|c|}
\hline \multirow{3}{*}{$\begin{array}{l}\text { Years in } \\
\text { Extension }\end{array}$} & \multicolumn{10}{|c|}{ Learning Style } \\
\hline & \multicolumn{2}{|c|}{ Assimilator } & \multicolumn{2}{|c|}{ Converger } & \multicolumn{2}{|c|}{ Accommodator } & \multicolumn{2}{|c|}{ Diverger } & \multicolumn{2}{|c|}{ Total } \\
\hline & $N$ & $\%$ & $N$ & $\%$ & $N$ & $\%$ & $N$ & $\%$ & $N$ & $\%$ \\
\hline $0-5$ years & 1 & 11.1 & 0 & 0.0 & 2 & 25.6 & 0 & 0.0 & 3 & 9.4 \\
\hline $6-10$ years & 1 & 11.1 & 4 & 36.4 & 4 & 57.1 & 3 & 60.0 & 12 & 37.5 \\
\hline $11-15$ years & 0 & 0.0 & 2 & 18.1 & 0 & 0.0 & 1 & 20.0 & 3 & 9.4 \\
\hline $16-20$ years & 1 & 11.1 & 1 & 9.1 & 0 & 0.0 & 0 & 0.0 & 2 & 6.3 \\
\hline 20 plus years & 6 & 66.7 & 4 & 36.4 & 1 & 14.3 & 1 & 20.0 & 12 & 37.5 \\
\hline Total & 9 & 100.0 & 11 & 100.0 & 7 & 100.0 & 5 & 100.0 & 32 & 100.0 \\
\hline
\end{tabular}


Table 9

Comparison of the Learning Style of Extensions Agents Responsible For Pesticide Recertification Programs in West Virginia with their Major Program Area

Learning Style

\begin{tabular}{lcccccccccc}
\hline \multirow{2}{*}{ Program Area } & Assimilator & \multicolumn{2}{c}{ Converger } & Accommodator & Diverger & \multicolumn{2}{c}{ Total } \\
\cline { 2 - 10 } & $N$ & $\%$ & $N$ & $\%$ & $N$ & $\%$ & $N$ & $\%$ & $N$ & $\%$ \\
\cline { 2 - 10 } Agriculture & 5 & 55.6 & 7 & 63.6 & 5 & 71.4 & 3 & 60.0 & 20 & 62.5 \\
4-H/Youth & 0 & 0.0 & 1 & 9.1 & 1 & 14.3 & 0 & 0.0 & 2 & 6.3 \\
All & 3 & 33.3 & 2 & 18.2 & 1 & 14.3 & 2 & 40.0 & 8 & 25.0 \\
Other & 1 & 11.1 & 1 & 9.1 & 0 & 0.0 & 0 & 0.0 & 2 & 6.3 \\
\hline Total & 9 & 100.0 & 11 & 100.0 & 7 & 100.0 & 5 & 100.0 & 32 & 100.0 \\
\hline
\end{tabular}

Crosstabs were used to compare gender with the learning styles of the agents. There were 23 males and nine female respondents in the study. Of those whose learning style was assimilator, eight $(88.9 \%)$ were male and one $(11.1 \%)$ was female. There were seven $(63.6 \%)$ males and four $(36.4 \%)$ female convergers. Five males $(74.1 \%)$ and two $(28.9 \%)$ females were accommodators. There were three $(60.0 \%)$ male and two $(40.0 \%)$ female divergers (see Table 10). A Cramer's V statistic failed to show a significant association between the factors. 
Table 10

Comparison of the Learning Style of Agents Responsible For Pesticide Re-Certification

Programs in West Virginia with their Gender

Learning Style

\begin{tabular}{lcccccccccc}
\hline \multirow{2}{*}{ Gender } & \multicolumn{2}{c}{ Assimilator } & \multicolumn{2}{c}{ Converger } & \multicolumn{2}{c}{ Accommodator } & \multicolumn{2}{c}{ Diverger } & \multicolumn{2}{c}{ Total } \\
\cline { 2 - 10 } & $N$ & $\%$ & $N$ & $\%$ & $N$ & $\%$ & $N$ & $\%$ & $N$ & $\%$ \\
\cline { 2 - 10 } Male & 8 & 88.9 & 7 & 63.6 & 5 & 74.1 & 3 & 60.0 & 23 & 71.9 \\
Female & 1 & 11.1 & 4 & 36.4 & 2 & 28.9 & 2 & 40.0 & 9 & 28.1 \\
\hline Total & 9 & 100.0 & 11 & 100.0 & 7 & 100.0 & 5 & 100.0 & 32 & 100.0 \\
\hline
\end{tabular}

Crosstabs were used to compare the area of their Bachelor's degree with the learning styles of the agents. Of the agents categorized as assimilators, two (22.2\%) majored in animal science, three (33.4\%) in agriculture education, two $(22.2 \%)$ in plant and soil science, and two $(22.2 \%)$ in other areas of study. A total of 11 agents were categorized as convergers. Among these agents, four (36.4\%) studied animal science, three (27.2\%) studied plant and soil science, and four (36.4\%) studied one of the other areas to obtain their Bachelor's Degree. Of the seven agents categorized as accommodators, one (14.2\%) earned a Bachelor's Degree in agriculture education and three (42.9\%) agents each obtained their degree in plant and soil science and other study areas. There were five agents who were categorized as divergers. Of these agents, two (40.0\%) agents each earned their degree in animal science and plant and soil science. One $(20.0 \%)$ agent earned their degree in one of the other areas of study listed above (see Table 11). 
A Cramer's V statistical procedure failed to reveal a significant relationship between the variables.

Table 11

Comparison of the Learning Style of Extensions Agents Responsible for Pesticide ReCertification Programs in West Virginia with their Study Are of their Bachelor Degree

\begin{tabular}{|c|c|c|c|c|c|c|c|c|c|c|}
\hline \multirow{3}{*}{$\begin{array}{l}\text { Bachelor } \\
\text { Degree }\end{array}$} & \multicolumn{10}{|c|}{ Learning Style } \\
\hline & \multicolumn{2}{|c|}{ Assimilator } & \multicolumn{2}{|c|}{ Converger } & \multicolumn{2}{|c|}{ Accommodator } & \multicolumn{2}{|c|}{ Diverger } & \multicolumn{2}{|c|}{ Total } \\
\hline & $N$ & $\%$ & $N$ & $\%$ & $N$ & $\%$ & $N$ & $\%$ & $N$ & $\%$ \\
\hline Animal Science & 2 & 22.2 & 4 & 36.4 & 0 & 0.0 & 2 & 40.0 & 8 & 25.0 \\
\hline $\begin{array}{l}\text { Agricultural } \\
\text { Education }\end{array}$ & 3 & 33.4 & 0 & 0.0 & 1 & 14.2 & 0 & 0.0 & 4 & 12.5 \\
\hline $\begin{array}{l}\text { Plant \& Soil } \\
\text { Science }\end{array}$ & 2 & 22.2 & 3 & 27.2 & 3 & 42.9 & 2 & 40.0 & 10 & 31.3 \\
\hline Other & 2 & 22.2 & 4 & 36.4 & 3 & 42.9 & 1 & 20.0 & 10 & 31.3 \\
\hline Total & 9 & 100.0 & 11 & 100.0 & 7 & 100.0 & 5 & 100.0 & 32 & 100.0 \\
\hline
\end{tabular}

Crosstabs were used to compare the area of their Master's degree with the learning styles of the agents. Of the nine agents categorized as assimilators, two $(22.2 \%)$ earned their degree in animal science, one (11.2\%) earned his or her degree in agriculture education, and three (33.3\%) each earned their Master's Degree in plant \& soil science and other areas of study. Eleven agents were categorized as convergers. Two (18.2\%) of these agents earned their Master's degree in animal science, four (36.4\%) in plant \& soil science, and five (45.4\%) in other areas of study. 
The agents who were categorized as accommodators were included three (42.9\%) agents in plant \& soil science and four (57.1\%) agents in other areas of study. Of the agents whose learning style was a diverger, one (20.0\%) agent each earned their degree in animal science and other areas of study. Three $(60.0 \%)$ of these agents earned their degree in plant \& soil science (see Table 12). Statistical analysis failed to show a significant relationship between the variables.

Table 12

Comparison of the Learning Style of Agents Responsible for Pesticide Re-Certification

Programs in West Virginia with the Study Area of their Master's Degree

\begin{tabular}{|c|c|c|c|c|c|c|c|c|c|c|}
\hline \multirow{3}{*}{$\begin{array}{l}\text { Master's } \\
\text { Degree }\end{array}$} & \multicolumn{10}{|c|}{ Learning Style } \\
\hline & \multicolumn{2}{|c|}{ Assimilator } & \multicolumn{2}{|c|}{ Converger } & \multicolumn{2}{|c|}{ Accommodator } & \multicolumn{2}{|c|}{ Diverger } & \multicolumn{2}{|c|}{ Total } \\
\hline & $N$ & $\%$ & $N$ & $\%$ & $N$ & $\%$ & $N$ & $\%$ & $N$ & $\%$ \\
\hline Animal Science & 2 & 22.2 & 2 & 18.2 & 0 & 0.0 & 1 & 20.0 & 5 & 15.6 \\
\hline $\begin{array}{l}\text { Agricultural } \\
\text { Education }\end{array}$ & 1 & 11.2 & 0 & 0.0 & 0 & 0.0 & 0 & 0.0 & 1 & 3.1 \\
\hline $\begin{array}{l}\text { Plant \& Soil } \\
\text { Science }\end{array}$ & 3 & 33.3 & 4 & 36.4 & 3 & 42.9 & 3 & 60.0 & 13 & 40.6 \\
\hline Other & 3 & 33.3 & 5 & 45.4 & 4 & 57.1 & 1 & 20.0 & 13 & 40.6 \\
\hline Total & 9 & 100.0 & 11 & 100.0 & 7 & 100.0 & 5 & 100.0 & 32 & 100.0 \\
\hline
\end{tabular}

Crosstabs were used to compare age with the learning styles of the agents. Of the nine assimilators, two $(22.2 \%)$ were in the $31-40$ category, four $(44.4 \%)$ were in the age $41-50$ category, and three $(33.4 \%)$ were 50 or more years in age. Eleven agents were categorized as 
convergers. Three $(27.3 \%)$ were in the age $31-40$ category, five $(45.5 \%)$ were in the $41-50$ age category, and three $(27.3 \%)$ were age 50 or more. There were seven agents categorized as accommodators, of which two (28.9\%) were in the $31-40$ age category, four (57.1) were in the 41 - 50 age category, and one (14.3\%) agent was 50 years or more in age. Of the five agents categorized as divergers, there was one (20.0\%) agent each in the age categories of $21-30$ years, $31-40$ years, and $41-50$ years. Two (40.0\%) agents were 50 years or more in age (see Table 13). A Cramer's V failed to show a significant relationship between the variables.

Table 13

Comparison of the Learning Style of Extensions Agents Responsible For Pesticide ReCertification Programs in West Virginia with their Age

\begin{tabular}{lcccccccccc}
\hline & \multicolumn{8}{c}{ Learning Style } \\
\hline \multirow{2}{*}{ Age } & \multicolumn{1}{c}{ Assimilator } & Converger & Accommodator & Diverger & Total \\
\cline { 2 - 10 } & $N$ & $\%$ & $N$ & $\%$ & $N$ & $\%$ & $N$ & $\%$ & $N$ & $\%$ \\
\cline { 2 - 10 } $21-30$ years & 0 & 0.0 & 0 & 0.0 & 0 & 0.0 & 1 & 20.0 & 1 & 3.1 \\
$31-40$ years & 2 & 22.2 & 3 & 27.3 & 2 & 28.9 & 1 & 20.0 & 8 & 25.0 \\
$41-50$ years & 4 & 44.4 & 5 & 45.5 & 4 & 57.1 & 1 & 20.0 & 14 & 43.8 \\
50 or more years & 3 & 33.4 & 3 & 27.3 & 1 & 14.3 & 2 & 40.0 & 9 & 28.1 \\
\hline Total & 9 & 100.0 & 11 & 100.0 & 7 & 100.0 & 5 & 100.0 & 32 & 100.0 \\
\hline
\end{tabular}




\author{
CHAPTER V \\ Summary, Conclusions and Recommendations
}

\title{
Purpose of the Study
}

The purpose of this study was to determine the learning style preferences of Extension agents responsible for pesticide re-certification training programs in West Virginia. The information may be helpful in improving the learning environments of private pesticide applicators. By using the theories of Kolb, this study proposes a method of determining learning styles and discovering relationships that may exist between the agents' learning style and their basic demographic information. An identification of agents' learning styles has implications for their teaching styles and the way they interact with clients. The information may help Extension agents provide more effective learning environments to their adult clientele as well as help provide insight to the effectiveness of the pesticide re-certification training program in West Virginia.

\section{Research Objectives}

The following research objectives gave direction to the study:

1. Categorize West Virginia Extension agents as diverger, converger, assimilator, or accommodator according to their scores on Kolb's Learning Style Inventory (LSI).

2. Determine if a correlation exists between agents' learning style and their primary program area.

3. Determine if a correlation exists between agents' learning styles and their years of Extension experience.

4. Determine if a correlation exists between agents' learning style and their age

5. Determine if a correlation exists between agents' learning style and their gender. 
6. Determine if a correlation exists between agents' learning style and the area of study they earned their Bachelor degree

7. Determine if a correlation exists between agents' learning style and the area of study they earned their Master's degree.

\section{Research Questions}

The following research questions were answered during this study:

1. What were the learning styles of Extension agents that teach pesticide re-certification training programs in West Virginia?

2. Were there relationships between an Extension agent's learning style and their years of extension experience, program area, gender, area of study of their Bachelor and Master's degrees and age?

3. If these relationships exist, can these factors offer the probability of learning style preference?

\section{Summary}

Kolb's Learning Style Inventory (LSI) (Kolb, 1985) was used to determine the learning style of extension agents who are responsible for delivering pesticide re-certification programs in West Virginia. Forty-eight extension agents, whose program responsibilities include pesticide re-certification, were mailed Kolb's LSI and a demographic survey that was used to determine certain characteristics, such as years of extension experience, major program area, study area of the agent's Bachelor and Master's degree, age and gender. Kolb's LSI was used to categorize each agent as an assimilator, converger, diverger or accommodator, depending on their responses on the LSI. Thirty-four of the 48 agents surveyed responded to the mailing. Two respondents were excluded from the study. One agent was no longer employed with the WVU Extension 
Service and the other respondent did not have program responsibilities in pesticide recertification. A response rate of $69.5 \%$ was obtained.

Summary of Demographic Information. Agents participating in the study were asked to respond to a basic demographic survey. Most agents who responded to the survey either had six to 10 years or more than 20 years of Extension experience. Nearly three-fourths of the agents were male. Slightly less than two-thirds of the agents stated their major program area was agriculture. One-fourth of the agents had program responsibilities in all three areas of agriculture, 4-H/youth and family and consumer sciences. Agents were asked to state the study area in which they earned their Bachelor and Master's degree. For the Bachelor Degree, less than three-eighths of the agents earned their Bachelor degree in plant and soil science and other areas of study, respectively. For the Master's Degree, more than three-eighths of the agents earned their degree in Plant and Soil Science and other areas of study, respectively. A majority of the agents were between the ages of 41 and 50 .

Summary of Learning Style Determinations. Kolb's LSI was used to determine the learning style preference of each agent. A majority of the agents were found to be convergers. A little more than one-fourth of the agents were categorized as assimilators while less than onefourth of these agents were found to be accommodators. A little more than one-eighth of the agents were divergers. None of the demographic factors had a significant association with learning style.

\section{Conclusions}

Three research questions were answered by the results of this study. The first question sought to categorize each agent according to their learning style preference as determined by Kolb's LSI. Converger was the most frequent learning style preference overall. Similar results 
were found with other studies using Kolb’s LSI (Yoder \& Rollins, 1992; Joerger \& Persons, 1993; Rollins \& Yoder, 1993; Park \& Gamon, 1996). The second question sought to discover any relationships that may exist between agents' learning style, determined by Kolb's LSI, and their years of Extension experience, major program area, gender, area of study of their Bachelor and Master's degree and age. These relationships were not significant at an alpha level of 0.05 . It can be concluded from the results of this study that Extension experience, major program area, gender, age and study area of Bachelor and Master's degree have little or no relevance to an Extension agent's learning style preference. Therefore, the third question as to whether or not these factors offer the probability of predicting learning style preference has been answered. Because no significant relationship exists between learning style and basic demographic information, these factors cannot be an indicator of an agent's learning style preference. What does all this mean for Extension specialists who plan training programs for Extension agents providing pesticide re-certification opportunities to private pesticide applicators? When developing educational programs, Extension specialists need to be aware of the diverse backgrounds of the agents who are participating. A majority of the agents participating in this study would learn well in environments that apply theories to problem solving. However, not all of these agents responsible for pesticide re-certification in West Virginia have the ability to learn in this manner. As a result, various teaching methods will need to be employed to communicate principles of pest management effectively.

New employee learning style preferences should also be a concern for Extension specialists in West Virginia. Based on the results of this study, a majority of the agents were between the ages of 41 and 50, indicating that a large portion of the agents responsible for pesticide re-certification will be eligible for retirement within the next ten years. It can be 
concluded that the over all dynamics of the agents participating in the study has the potential of changing significantly due to employee turnover. Extension specialists responsible for agent training in pesticide re-certification will need to be aware of the change in the overall group characteristics and take steps to determine new employee learning style preferences. The information will enable the Extension specialists to present new pest management concepts in a manner conducive to the learning style preferences of the group as a whole.

\section{Recommendations}

Extension agents responsible for pesticide re-certification training programs need to be aware of the implications their learning style has on their preferred manner of teaching. For example, if the agent's learning style is a Converger, then they most likely will direct their programs in such a manner that the practical application of a theory will be a learning outcome. However, given that the agriculture community is becoming more diverse, some individuals participating in the pesticide re-certification program may not possess the ability to grasp the information in the manner it is being presented. In general, it is recommended the Extension agent should employ some mechanism to determine how his or her clientele prefer to learn new information concerning pest management.

Further study of the adult learning environment is recommended. Does the learning style of the instructor have any influence on their preferred teaching methods? Are there relationships that exist between an instructor's learning style and their preferred teaching method? The development of a Likert-type instrument to measure an agent's comfort level with different teaching methods may be helpful in gathering information in making relationship determinations between learning style and teaching methods. 
Research concerning the reliability of Kolb's LSI as it relates to Extension populations is limited or non-existent. Further research is also recommended to determine if an Extension agent's learning style classification is stable over time. A reliability study concerning this topic would lend insight to the effectiveness of Kolb's LSI in Extension research. 


\section{REFERENCES}

Ary, D., Jacobs, L., Razavieh, A. (1996). Introduction to Research in Education. New York: Holt, Rinehart and Winston, Inc.

Atherton, J.S. (2003) Learning and Teaching: Knowles' Andragogy [On-line] UK: Available: http://www.dmu.ac.uk/ jamesa/learning/knowlesa.htm.

Bhardwaj, A. \& Miller, L. E. (1993). Cognitive Levels of Education Programs Offered by the County Agricultural Extension Agents of Ohio Cooperative Extension Service. Proceedings of the Annual National Agricultural Education Research Meeting. USA. 6067.

Biehler, R. \& Snowman, J. (2003). Psychology Applied to Teaching. New York: Houghton Mifflin Company

Blackmore, J. 1996. Pedagogy: Learning Styles. Telecommunications for Remote Work and Learning. www.cyg.net/ jblackmo/diglib/styl-a.html.

Caffarella, R. S. \& Barnett, B. G.1994. Characteristics of Adult Learners and Foundations of Experiential Learning. New Directions for Adult and Continuing Education, 62, 29-42.

Cantor, J. A. (1992) Delivering Instruction to Adult Learners. Toronto: Wall \& Emerson. (pp. 35-43).

Cranton, P. (1992) Working with Adult Learners. Toronto: Wall \& Emerson. (pp. 13-15 and 40$63)$.

Davis, J. A. (1971). Elementary Survey Analysis. Englewood, NJ: Prentice Hall.

Geiger, M. A., \& Boyle, E. J. (1992). Learning Styles of Students and Instructors: An Analysis of Course Performance and Satisfaction. The Accounting Educator's Journal, 4, 86-101.

Geiger, M. A., \& Pinto, J. K. (1991). Changes in Learning Style Preference During a Three-Year Longitudinal Study. Psychological Reports, 69, 755-762.

Geiger, M. A., Boyle, E.J., \& Pinto, J.K. (1992). A Factor Analysis of Kolb's Revised Learning Style Inventory. Educational and Psychological Measurement , 52, 753-759.

Geiger, M. A., Boyle, E. J., \& Pinto, J. K. (1993). An examination of ipsative and normative versions of Kolb's revised Learning Style Inventory. Educational and Psychological Measurement, 53, 717-728.

Field, R. (2001). John Dewey (1859-1952). The Internet Encyclopedia of Philosophy. Retrieved April 5, 2004, http://www.utm.edu/research/iep/d/dewey.htm. 
Hartman, V. F.1995. Teaching and learning style preferences: Transitions through technology. VCCA Journal 9,no.2 Summer: 18-20. www.so.cc.va.us/vcca/hart1.html.

Hwang, D. Y. \& Henson, R. K. (2002). A Critical Review of the Literature on Kolb's Learning Style Inventory with Implications for Score Reliability. Paper presented at the Annual Meeting of the Southwest Educational Research Association. (Austin, TX, February 1416, 2002).

Joerger, R. \& Persons, Edgar (1993). Cognitive Learning Style Preferences of the Minnesota Farm Business Management Educators. Proceedings of the Annual National Agricultural Education Research Meeting. USA. 95-100.

Kolb, D. A. (1976b). Learning Style Inventory : Technical Manual. Boston: McBer \& Co.

Kolb, D. A. (1984). Experience Learning: Experience as the Source of Learning and Development. New Jersey: Prentice-Hall.

Kolb, D. A. (1985). Learning Styles Inventory. Boston, Massachusetts. McBer and Company

Kolb, D. A. (1985). The Learning Style Inventory: Technical Manual. Boston: McBer \& Co.

Lattal, K. A. (1998). A Century of Effect: Legacies of E. L. Thorndike's Animal Intelligence Monograph. Journal of Experimental Analysis of Behavior, 76, 325-336.

Lewin, K. (1948) Resolving Social Conflicts; Selected Papers on Group Dynamics. Gertrude W. Lewin (ed.). New York: Harper \& Row, 1948.

Miller, L. E. \& Ismail, A. 1993.Assessing the Intended and Actual Levels of Cognition in Ohio Cooperative Extension Service County Agricultural Agents'/State Specialists' Instructional Programs. Proceedings of the Annual Central Region Research Conference in Agricultural Education. USA. 164-174

National Association of State Universities and Land-Grant Colleges (1995). The Land-Grant Tradition. Retrieved April 5, 2004, www.nasulgc.org/publications/Land_Grant/Land_Grant_Main.htm.

Newcomb, L. H., \& Trefz, M. K. (1987). Levels of Cognition of Students' Tests and Assignments in the College of Agriculture at The Ohio State University. Proceedings of the Central Region 41 ${ }^{\text {st }}$ Annual Research Conference in Agricultural Education. Chicago, IL.

Nunnally, J. C., \& Bernstein, I. H. (1994). Psychometric Theory. New York: McGraw-Hill.

O'Donnell, J. M. (1985). The origins of behaviorism: American psychology 1870-1920. New York: New York University Press. 
Okoro, D. \& Miller, L. E. 1994. Factors Related to the Learning of Participants in the Ohio Pesticide Private Applicators Instructional Program. (Summary of Research 77). Columbus,OH: Department of Agriculture Education. (ERIC Document Reproduction Service No. ED 372 209)

Park, S. \& Gamon, J. 1996. Designing Inservice Education for Extension Personnel: The Role of Learning Styles in Computer Training Programs. Journal of Applied Communications, 80, no 4: $15-23$

Pure Food and Drug Act of 1906. United States Statutes at Large. $59^{\text {th }}$ Congress, Session I, Chapter 3915, p. 768-772

Richardson, J. 1995. Assessment of Clientele Preference for Receiving Extension Information. Proceedings of the 44th Annual Southern Agricultural Education Research Meeting. USA. 310-319.

Richardson, J. (1994). Learning Best Through Experience. Journal of Extension 32 no. 2 August. www.joe.org.

Rollins, T. J. \& Yoder, E. P. (1992). Position Assignment and Learning Styles of Extension Agents. Proceedings of the Midwest Research-to-Practice Annual Conference in Adult and Continuing and Community Education. (1 ${ }^{\text {th }}$, Manhattan, Kansas, October 8-9, 1992).

Rollins, T. J., \& Yoder, E. P. (1993). Adult Learning Preferences: A Profile of Extension Educators. Journal of Agriculture Education,31, no.1: 18-25.

Ruble, T. L., \& Stout, D. E. (1990). Reliability, Construct Validity and Response-set Bias of the Revised Learning Style Inventory. Educational and Psychological Measurement, 50, 619-629.

Ruble, T. L., \& Stout, D. E. (1991). Reliability, Classification Stability, and Response-set Bias of Alternate Forms of the Learning Style Inventory. Educational and Psychological Measurement, 51, 481-489.

Ruble, T. L. \& Stout, D. E. (1994). A Critical Assessment of Kolb's Learning Style Inventory. Assessment and Evaluation. (ED377221)

Sims, R. R., Veres, J. G., III, Watson, P., \& Buckner, K. E. (1986). The Reliability and Classification Stability of the Learning Style Inventory. Educational and Psychological Measurement, 46, 753-760.

Sims, R. R., Veres, J. G.,III, \& Shake, L. G. (1989). An Exploratory Examination of the Convergence Between the Learning Styles Questionnaire and the Learning Style Inventory II. Educational and Psychological Measurement, 49, 227-233. 
Smith, M. K. (2001) 'David A. Kolb on experiential learning', The Encyclopedia of Informal Education, Retrieved April 5, 2004, http://www.infed.org/b-explrn.htm.

Smith, M. K. (2001) 'Kurt Lewin, groups, experiential learning and action research', the encyclopedia of informal education, Retrieved April 5, 2004, http:// www.infed.org/thinkers/et-Lewin.htm.

Thorndike, E. L. (1898). Animal intelligence: An experimental study of the associative processes in animals. Psychological Review Monograph Supplements, 2, 94, Whole No. 8.

Trede, L. D. \& Whitaker, S. (1998). Beginning Farmer Education in Iowa: Implications to Extension. Journal of Extension,36, no5. www.joe.org.

Pure Food and Drug Act of 1906, Pub. L. No.59 § 34 Stat. 768-772.

U.S. Environmental Protection Agency (2004). FIFRA Statute, Regulations \& Enforcement. Retrieved April 5, 2004, www.epa.gov/compliance/civil/programs/fifra/fifraenfstatreq.html.

Veres, J. G., III, Sims, R. R., \& Shake, L. G. (1987). The Reliability and Classification Stability of the Learning Style Inventory in Corporate Settings. Educational and Psychological Measurement, 47, 1127-1133.

Wells, J. B., Layne, B. H., \& Allen, D. (1991). Management Development Training and Learning Styles. Public Productivity and Management Review, 14, 415-428.

West Virginia Pesticide Control Act of 1990, 19 West Virginia Statutes §16A-2

West Virginia University Extension Service (2004). What It Is and Who It Serves. Retrieved April 5, 2004, http://www.wvu.edu/ exten/about/whatwho.htm.

West Virginia University Extension Service (2000).Guidelines for Pesticide Recertification Training Programs. Retrieved January 15, 2000, www.wvu.edu/ agextem/ipm/pestprog/educate/recerreq.htm. 


\section{APPENDICES}




\section{APPENDIX A}

Mailing Cover Letter 
March 2, 2000

\section{Dear Extension Agent:}

As part of a thesis in Agricultural and Environmental Education at West Virginia University, we are conducting a study to determine learning styles of Extension agents involved in pesticide re-certification programs, a study designed to provide information that may be helpful in improving the delivery of pesticide re-certification offerings. To do this, we need your assistance.

Enclosed you will find a copy of Kolb's Learning Style Inventory (LSI) and a survey to gather demographic information about yourself and your position. Please complete all portions of the LSI and the survey, including your name and position location. If there are any question that you would rather not answer, leave them blank. This information will be kept confidential and will not be released on any reports. Research materials will be kept in Dr. Lawrence's office and data will be used only for thesis completion. Approximately five minutes will be required to complete the LSI and the survey form.

While your participation in this study is strictly voluntary, we do need your help in order to provide the most useful information. If you have any questions regarding this research, please feel free to contact Ms. Custer at (304)599-7718 or Dr. Layle Lawrence at (304) 293-3431. Your cooperation and support of this endeavor are greatly appreciated. Please remember to complete and return all enclosures. Please take a few minutes, complete both forms, and mail them back to us in the enclosed envelope right away. Thank you!

Sincerely,

Anne Custer

Graduate Student

Dr. Layle Lawrence

Faculty Advisor 


\section{APPENDIX B}

Demographic Survey 


\section{SURVEY FORM}

Please complete the following questions and return with Kolb's Learning Style Inventory.

1. How many years have you served as an Extension agent?
( ) $0-5$
( ) $6-10$
( ) $11-15$
( ) $16-20$
( ) $20+$

2. What is your major program area?
( ) Agriculture
( ) 4-H/Youth
( ) Family \& Consumer Sciences
( ) All

3 . What is your gender?
( ) Male
( ) Female

4. In what area is your Bachelor's degree?
( ) Animal Science
( ) Agricultural Education
( ) Plant \& Soil Science
( ) Other:

5. In what area is your Master's degree?
( ) Animal Science
( ) Agricultural Education
( ) Plant \& Soil Science
( ) Other:

6. What is your age?
( ) $21-30$
( ) $31-40$
( ) $41-50$
( ) more than 50 
APPENDIX D

Follow-up Letter 
April 11, 2000

Dear Extension Agent:

On March 2, 2000, I wrote to you requesting your voluntary response in completing a Kolb's Learning Style Inventory and a demographic survey. As of today, I have not received your response. These information-gathering materials are being used to study the learning styles of Extension agents offering programs in pesticide re-certification training programs. Your response is needed in order for the results of this study to be accurate.

Please complete the Learning Style Inventory, as well as the survey of demographic information as soon as possible. A return envelope has been provided to you. I appreciate your participation in this study. I look forward to receiving your response. If these items have already been completed and returned, your help is greatly appreciated.

Sincerely,

Anne M. Custer

Graduate Student

Agricultural and

Environmental

Education 
VITA

Education:

May 2004
April 2000 to Present
Professional
Experience:
Bachelor of Science

Agronomy

West Virginia University

Morgantown, West Virginia

Master of Science

Agricultural and Environmental

Education

West Virginia University

Morgantown, West Virginia

United States Department of Agriculture

Farm Service Agency

Farm Loan Officer

Lewisburg, West Virginia 
Learning Styles of Extension Agents Responsible for Pesticide Re-Certification Training Programs in West Virginia

Anne M. Custer-Walker

Thesis submitted to the Davis College of Agriculture, Forestry, and Consumer Sciences at West Virginia University in partial fulfillment of the requirements for the degree of

Master of Science

in

Agricultural Education

Division of Resource Management

APPROVAL OF THE EXAMINING COMMITTEE

Stacy A. Gartin, Ph.D., Chair

Harry N. Boone, Jr., Ph.D.

April 8, 2004

Jean M. Woloshuk, Ed.D. 